\title{
$\beta$-Carbolines in Experiments on Laboratory Animals
}

\author{
Renata Zawirska-Wojtasiak ${ }^{1, *}$, Agnieszka Fedoruk-Wyszomirska ${ }^{2,+}+\mathbb{C}$, Paulina Piechowska ${ }^{1}$, \\ Sylwia Mildner-Szkudlarz ${ }^{1}{ }^{\circledR}$, Joanna Bajerska ${ }^{1}{ }^{\circledR}$, Elżbieta Wojtowicz $^{3}$, Krzysztof Przygoński $^{3}$, \\ Dorota Gurda ${ }^{2}$, Wiktoria Kubicka ${ }^{2}$ and Eliza Wyszko ${ }^{2, *(1)}$ \\ 1 Faculty of Food Science and Nutrition, Poznań University of Life Sciences, Wojska Polskiego 28, \\ 60-637 Poznań, Poland; paulina.piechowska@up.poznan.pl (P.P.); \\ sylwia.mildner-szkudlarz@up.poznan.pl (S.M.-S.); joanna.bajerska@up.poznan.pl (J.B.) \\ 2 Institute of Bioorganic Chemistry, Polish Academy of Sciences, Noskowskiego 12/14, 61-794 Poznań, Poland; \\ agaw@ibch.poznan.pl (A.F.-W.); d_gurda@ibch.poznan.pl (D.G.); wiktoriakubicka.k@gmail.com (W.K.) \\ 3 Department of Food Concentrates and Starch Products, Prof. Wacław Dabrowski Institute of Agricultural \\ and Food Biotechnology, Starołęcka 40, 61-361 Poznań, Poland; ewojt@man.poznan.pl (E.W.); \\ krisp@man.poznan.pl (K.P.) \\ * Correspondence: renazaw@up.poznan.pl (R.Z.-W.); eliza.wyszko@ibch.poznan.pl (E.W.) \\ + Equally contributed as the first author.
}

Received: 22 June 2020; Accepted: 21 July 2020; Published: 24 July 2020

check for updates

\begin{abstract}
Some studies have ascribed a protective effect against neurodegenerative diseases to the $\beta$-carbolines harman $(\mathrm{H})$ and norharman $(\mathrm{NH})$, which occur mostly in coffee and coffee substitutes. We determined the concentrations of $\beta$-carbolines and undesirable compounds (such as acrylamide) in roasted coffee substitute ingredients and found that chicory coffee was optimal. Two in vivo experiments were conducted with seventeen-month-old male Sprague Dawley rats fed a diet with the addition of pure carboline standards in the first stage, and chicory in the second. We observed an increase in the level of $\mathrm{H}$ and $\mathrm{NH}$ in blood plasma, as well as higher activity of animals in the battery behavioral test, particularly in the second stage. The results of in vitro studies-particularly the level of the expression in brain tissue of genes associated with aging processes and neurodegenerative diseases-clearly show the benefits of a diet rich in $\beta$-carbolines.
\end{abstract}

Keywords: $\beta$-carbolines; chicory; rats; behavioral tests; in vitro experiments

\section{Introduction}

$\beta$-carbolines are biologically active, naturally occurring plant-derived alkaloids that are derivatives of indole. Norharman $(\mathrm{NH})$ and harman $(\mathrm{H})$ are the most frequently identified $\beta$-carbolines. The literature has reported the presence of $\mathrm{NH}$ and $\mathrm{H}$ in processed and stored food [1,2]. In recent years, attention has turned to the neuroactive effects of $\mathrm{NH}$ and $\mathrm{H}$ [3,4]. Carbolines can act as neuromodulators through their effect on monoamine oxidase (MAO), which may lead to depression, Parkinson's disease (PD), and Alzheimer's disease [4]. However, some studies on carbolines have suggested that there may be specific MAO inhibitors. Research on the expression of this enzyme focuses on effectively inhibiting its action, which would allow treatment of both affective disorders and Parkinson's disease $[5,6]$. Monoamine oxidase inhibitors were among the first antidepressants to be discovered [5]. Studies on the activity of MAO in tobacco point to the high level of enzyme inhibitors in the form of $\mathrm{NH}$ and $\mathrm{H}$ in the brain of smokers [2]. It was also shown by other authors [7] that a potent monoamine oxidase inhibitor and stimulant is $\mathrm{H}$, while $\mathrm{NH}$ has a calming effect on the body. There have been few animal experiments performed with these compounds and diseases $[3,8]$. Some studies have investigated their antidepressant action on mice, showing that positive effects were associated with the addition of $\beta$-carbolines to experimental feed ( $\mathrm{H}$ and $\mathrm{NH}$, in doses of $5-15 \mathrm{mg} / \mathrm{kg}$ i.p. and $2.5-10 \mathrm{mg} / \mathrm{kg}$ 
i.p., respectively) [8]. Positive effects were also observed by Celikyurt et al. [3] in rats, where $\mathrm{H}$ was administered in doses of $2.5 \mathrm{mg} / \mathrm{kg}, 5.0 \mathrm{mg} / \mathrm{kg}$, and $7.5 \mathrm{mg} / \mathrm{kg}$, with the two higher doses leading to significantly fewer errors in working memory.

Li et al. [9] examined the bioavailability of $\beta$-carbolines on living organisms, using harman at $1 \mathrm{mg} / \mathrm{kg}$ and $30 \mathrm{mg} / \mathrm{kg}$ body weight; they calculated its bioavailability as $19.41 \%$ via oral administration.

Experimentation on animals (usually mice, hamsters, and rats) allows the actions and effects of compounds to be assessed. Carbolines added to fodder or intraperitoneally have been measured in the blood and organ before and after death $[3,10]$. There have been studies of the supplementation of fodder with natural sources of carbolines, such as coffee substitute. Some compounds play a neuroprotective role through the synthesis of active molecules, activation of appropriate receptors, or exertion of an effect on enzymatic changes, thus preventing the degradation of neurons and inhibiting the massive loss of important cells. The main obstacle, as for medicines, is likely to be the blood-brain barrier, which protects the brain against external factors while limiting the absorption of drugs [11].

An alternative to animal experiments in studying this phenomenon is represented by modern in vitro experiments on cell lines; however, according to Martinez-Morales and Liste [12], progress here can be difficult because of the lack of predictive and other cellular models. Nonetheless, some significant observations have been made in relation to Parkinson's disease in such studies.

Our literature review strongly suggests that some foods, especially coffee, can act as a rich source of $\beta$-carbolines, which may be associated with a reduced risk of serious neurodegenerative diseases, such as Parkinson's and Alzheimer's [13]. Human cancer cell lines have also been used in studies on the antitumor effects of some carboline derivatives [14].

The aim of our study is to use an animal experiment to determine the neuroactive effect of $\beta$-carbolines supplied as pure compounds and in a natural source (coffee substitute). We examined the influence of $\beta$-carbolines on the condition of aged rats by behavioral tests and analysis of the expression level of genes associated with neurodegenerative changes, aging, and apoptosis in the brain tissue of treated animals. Moreover, to determine the biological effect of analyzed $\beta$-carbolines on aged human cells we investigate cytotoxicity, reactive oxygen species (ROS) activation, and cell cycle changes using two models of cell lines: MRC-5 derived from a male fetus and AG20445A from an old patient diagnosed with PD. Both cell models were suitable for further aging needed to conduct our research.

The research hypothesis is that adding $\beta$-carbolines to the feed in the form of a coffee substitute protects experimental animals from neurodisorders.

\section{Materials and Methods}

\subsection{Chemical Standards}

Chemical standards of harman and norharman were sourced from Fluka, Steinheim, Germany and Sigma-Aldrich, Steinheim, Germany. Other chemicals came from Sigma-Aldrich or AlfaChem, Poznań, Poland.

\subsection{Raw Materials}

Dried chicory (Cichorium intybus) was obtained from the production plant of Cykoria, Wierzchosławice, Poland.

\subsection{The Experimental Diet}

The experimental diet was prepared by ZooLab (Urszula Borgiasz, Sędziszów, Poland) from corn starch $465.69 \mathrm{~g} / \mathrm{kg}$, casein (>85\% of proteins) $140.00 \mathrm{~g} / \mathrm{kg}$, maltodextrins $155.00 \mathrm{~g} / \mathrm{kg}$, sucrose $100.00 \mathrm{~g} / \mathrm{kg}$, soya oil (without additives) $40.00 \mathrm{~g} / \mathrm{kg}$, fiber ( $\alpha$-cellulose), $50.00 \mathrm{~g} / \mathrm{kg}$, mineral mix $35.00 \mathrm{~g} / \mathrm{kg}$, vitamin mix $10.00 \mathrm{~g} / \mathrm{kg}$, l-cystine $1.80 \mathrm{~g} / \mathrm{kg}$, choline $2.50 \mathrm{~g} / \mathrm{kg}$, and tert-butylhydroquinone $0.008 \mathrm{~g} / \mathrm{kg}$ enriched with carbolines (for stage 1 of the experiment), in concentrations equivalent to the contents of these 
compounds found in coffee consumed by humans in a volume of $0,500,750$, and $1000 \mathrm{~mL}$ daily (H1: $10 \mu \mathrm{g} / \mathrm{kg}$ animal diet; H2: $15 \mu \mathrm{g} / \mathrm{kg}$ animal diet; H3: $20 \mu \mathrm{g} / \mathrm{kg}$ animal diet; NH1: $8 \mu \mathrm{g} / \mathrm{kg}$ animal diet; NH2: $12 \mu \mathrm{g} / \mathrm{kg}$ animal diet; NH3: $16 \mu \mathrm{g} / \mathrm{kg}$ animal diet) and with chicory at $12.5 \mathrm{~g} / \mathrm{kg}$ animal diet (stage 2).

\subsection{Animal Experiment}

The experiment was conducted in the animal housing facility at the Institute of Human Nutrition and Dietetics, Poznan University of Life Sciences, under conditions of natural light and with the temperature maintained during the experiment at $19-22{ }^{\circ} \mathrm{C}$, and with a relative humidity of $55-60 \%$. Seventeen-month-old male Sprague Dawley rats originating from a Charles River Laboratories farm were used in the experiment. The age of the rats corresponded to 51 years of human life [15]. For the first ten days of the experiment (the adaptation period), the rats were fed ad libitum with a standard laboratory diet and water. The experiment was conducted in two stages. In the first stage, after acclimatization, the animals were randomly divided into seven groups ( $n=6$ each). The control rats were fed the AIN-93M rodent diet. The experimental rats were fed the same diet enriched with harman or norharman standards at a concentration equivalent to its concentration in coffee consumed by humans in amounts of 500, 750, and $1000 \mathrm{~mL}$ daily. In the second stage of the study, after an acclimatization period, the animals were randomly divided into two groups ( $n=6$ each) and fed either the AIN-93M (control) diet or the same diet enriched with dried chicory, as a natural source of $\beta$-carbolines, in the amounts indicated during the first stage as being most effective for improving cognitive functions in the animals. There were no differences in body weight between the groups at the beginning of either stage of the experiment. All rats were provided ad libitum diet and water for the fourteen weeks of both experiments. The food consumption of the individual rats was monitored daily by measuring the difference between the amount of diet supplied each day and the amount of diet remaining. Feces were collected for ten days in the seventh week of the experiment, and water content, protein, fat, dietary fiber, and ash were determined using standard analytical methods. Body mass was measured every seven days using an electronic balance. At the end of the experiment, animals were subjected to a series of behavioral tests (classical labyrinth test) and the forced swim test (FST). Additionally, the animals in stage 2 of the experiment were subjected to the open field test (OFT). At the end of the study, and following $16 \mathrm{~h}$ of starvation, the animals were weighed and euthanized by a mixture of air and $\mathrm{CO}_{2}$ at a concentration of $30 \% / 70 \%$ using an Easy-Box Euthanasia System (Animalab, Poznań, Poland). They were then dissected to collect blood from the hearts for future biochemical analysis of $\beta$-carboline levels.

The animal study design was approved by the local animal studies bioethics committee in Poznan, Poland (approvals 51/2017 and 29/2019) and performed according to the European Communities Council Directive of 24 November 1986 (86/609/EEC).

\section{5. $\beta$-Carboline Determination in Feed, Chicory, and Animal Blood}

The $\beta$-carboline levels in chicory were measured following Wojtowicz, Zawirska-Wojtasiak, Przygoński, and Mildner-Szkudlarz [16], with some modifications of sample dose (1-4 g) and validation (repeatability of $\mathrm{H}$ and $\mathrm{NH} 8.9 \%$ and $5.8 \%$, recovery of $\mathrm{H}$ and $\mathrm{NH} 100.2 \%$ and $96.4 \%$ ). The extracts were separated on a Dionex LC HPLC system with a Supelco C18 column and an RF-2000 detector.

The $\beta$-carboline levels in the experimental diet were determined based on the method described by Adachi et al. [17], with appropriately selected process parameters. To increase the accuracy of the process, double cold extraction was used to extract the test compounds from the experimental feed. Hot extraction was not employed due to the danger of pasting. Seven trials were made.

Determining the $\beta$-carbolines in blood required special preparation of the samples, following Zheng, Wang, Barnes, Guan, and Louis [18]. The heparin and plasma collected in the course of the section were placed in liquid nitrogen and stored at $-20^{\circ} \mathrm{C}$. Immediately prior to extraction, the samples were brought to room temperature. For the analysis, samples of approximately $5-10 \mathrm{~mL}$ were used in 
duplicate from each individual. Initially, a sample of blood was placed in Falcon conical tubes $(50 \mathrm{~mL}$ capacity) and mixed with half the volume of $1.0 \mathrm{M} \mathrm{NaOH}(2: 1)$. The mixture was manually shaken at room temperature for about 1-2 $\mathrm{min}$, and then on a horizontal shaker for $30 \mathrm{~min}$, to break down blood cells and solubilize protein components. After shaking, the extraction solution was added to the samples in a volume equal to that of the mixture in the test tubes. The extraction solution consisted of ethyl acetate and methyl t-butyl ether in a ratio of 2:98. The extraction was carried out using a horizontal shaker at room temperature for $45 \mathrm{~min}$. After extraction, the mixture was centrifuged at $3000 \times g$ for $10 \mathrm{~min}$. The upper organic phase was removed and transferred to a new Falcon conical tube. Extraction on the sample was carried out an additional two times, and the organic phase was stored in a refrigerator until the extracts had combined. The combined extracts were then evaporated under dry nitrogen. The dry residue was dissolved in $0.5 \mathrm{~mL}$ of methanol. The samples prepared in this way were stored at $-19^{\circ} \mathrm{C}$.

The concentration of $\mathrm{H}$ and NH in these samples was then estimated by HPLC. A Dionex Instrument with a P680 pump, ASI-100 autosampler, TCC-100 thermostat, and RF-2000 fluorescence detector was used. Separation was performed on Thermo Science Hypersil C18 column $(3 \mathrm{~mm} \times 150.3 \mu \mathrm{m})$, heated to $30^{\circ} \mathrm{C}$; the injection volume was $50 \mu \mathrm{L}$. The mobile phase consisted of deionized water containing $0.03 \mathrm{M}$ sodium formate and $0.025 \mathrm{M}$ triafluoroacetic acid in $1 \mathrm{dm}^{3}(\mathrm{~A})$, and acetonitrile (B).

Gradient: $0 \min 0 \%$ B to $5 \min 20 \%$ B, $14 \min 20 \%$ B, $14.5 \operatorname{min~} 0 \%$ B, $19 \min 0 \%$ B. Fluorescence excitation was induced using a $300 \mathrm{~nm}$ wavelength, and detection was performed at $440 \mathrm{~nm}$. Peaks were identified by the expected retention times for $\mathrm{H}$ and $\mathrm{NH}$ standards. The calibration curve was determined based on the prepared standard solutions with known concentrations of $\beta$-carbolines ranging from 0 to $20 \mathrm{ng} / \mathrm{mL}$. The correlation coefficients were 0.9979 for $\mathrm{H}$ and 0.9983 for $\mathrm{NH}$. The recovery rates for harman and norharman were respectively $72.1 \%$ and $21.3 \%$. The results for $\mathrm{H}$ and $\mathrm{NH}$ were corrected for the designated recovery.

\subsection{Behavioral Tests}

\subsubsection{Classical Labyrinth Test}

A classic labyrinth $(110 \times 65 \mathrm{~cm})$ was used, with corridors about $15 \pm 15 \mathrm{~cm}$, located on the table raised $50 \mathrm{~cm}$ from the ground. The test was performed in an isolated behavioral testing room with a low-intensity white light source. The time needed to complete the route between the two points of departure and arrival was measured. After each trial, any urine and fecal matter was removed, and the labyrinth was cleaned.

\subsubsection{Open Field Test (OFT)}

The test was performed in a rectangular cage $(80 \times 40 \mathrm{~cm})$ with dark walls and a white floor. The animal was placed in the cage arena for five minutes and its behavior was recorded for later analysis, as mobility time, time spent in cage center, and self-grooming frequency. The OFT was always performed at the same time of day, and the cage was cleaned between each test [1].

\subsubsection{The Forced Swim Test (FST)}

The forced swim test was performed as described by Porsolt, Pichon, and Jalfre [19]. The experiment was performed in two sessions in an isolated behavioral testing room. In the first session, the pretest, animals were forced to swim for $15 \mathrm{~min}$. The second session, which was the actual test, was conducted $24 \mathrm{~h}$ after the pretest for 5 min only. A transparent cylinder with water at $23-25^{\circ} \mathrm{C}$ was used, with the water being freshly changed for every rat. After each test session, the animals were dried briefly with a towel and returned to their home cages. The animals' behavior was recorded using a video camera and scored manually. Rats were described as immobile if they performed no activity other than that required to maintain the head above the water. In addition to immobility time, episodes of head shakes were recorded. 


\subsection{Fecal Analysis}

The total dietary (TDF), soluble (SDF), and insoluble (IDF) dietary fiber content of the experimental diet, defatted prior to analysis, were determined following a method described by Asp, Johansson, Hallmer, and Siljeström [20]. The Kjeldahl method was used with a TecatoKjeltec 1026 distilling unit (Tecator AB, Höganäs, Sweden) to determine total fecal nitrogen and protein. Fat content was measured after extracting $5 \mathrm{~g}$ with petroleum ether in a Soxtec Avanti 2055 apparatus (FOSS Tecator AB, Höganäs, Sweden). Water content was estimated for all the feces of each rat, collected in glass tubes for ten days. Samples of $2 \mathrm{~g}$ were dried in an automatic air exchange dryer at $130{ }^{\circ} \mathrm{C}$ until constant weight, expressed as $\mathrm{g} / 100 \mathrm{~g}$ of feces. For ash content analysis, $5 \mathrm{~g}$ stool samples were weighed into a crucible, which were charred and then burned in a muffle furnace at $550{ }^{\circ} \mathrm{C}$ for $6 \mathrm{~h}$ until a constant weight was obtained. The average ash content was calculated as $\mathrm{g} / 100 \mathrm{~g}$ of feces.

\subsection{In Vitro Experiments}

The in vitro experiments were performed in the Laboratory of Subcellular Structure Analyses of the Institute of Bioorganic Chemistry of the Polish Academy of Sciences in Poznań.

\subsubsection{Cell Culture}

Normal human lung fibroblasts (MRC-5) were purchased from ECACC, and human skin fibroblasts isolated from a sixty-year-old man with Parkinson's disease (AG20445) were purchased from the Coriell Institute. The cells were cultured in Eagle's Minimum Essential Medium (EMEM, Corning) supplemented with antibiotics (Penicillin-Streptomycin Solution (ATCC) and 10\% or 15\% FBS (Sigma-Aldrich), respectively. Both cell lines were cultured at $37^{\circ} \mathrm{C}$, with the addition of $5 \% \mathrm{CO}_{2}$ to the atmosphere.

\subsubsection{Real-Time Cell Proliferation Analysis by xCELLigence System}

Cell proliferation analysis was performed using an xCELLigence system (Roche). The cells were seeded in sixteen-well E-plates (Roche) at a density of $7.5 \times 10^{3}$ per well. After $24 \mathrm{~h}$, the cells were treated with $\mathrm{H}, \mathrm{NH}$, and both in final concentrations of $1,5,10,25,50$, and $100 \mu \mathrm{M}$. The control cells were cultured in the supplemented medium only. The real-time proliferation of the cells was estimated based on impedance measurement, expressed as a Cell Index (CI) value. The CI was monitored at $30 \mathrm{~min}$ intervals from the time of plating for six days.

\subsubsection{Confocal Microscopy Analysis of Cell Viability}

Cells were seeded on a glass-bottom ten-well CELLview Slide $\left(34 \mathrm{~mm}^{2}\right.$, Greiner $)$ at a density of $1 \times 10^{4}$ per well, and incubated until $80 \%$ confluency and treated with $\mathrm{H}, \mathrm{NH}$, or $\mathrm{H} / \mathrm{NH}$ in a final concentration of 5,10 , and $25 \mu \mathrm{M}$. Cell viability was determined after $24 \mathrm{~h}$ using a LIVE/DEAD assay (Thermo Fisher Scientific), following the manufacturer's protocols. Live cell imaging was performed in FluoroBrite DMEM (Thermo Fisher Scientific) using a Leica TCS SP5 confocal laser scanning microscope with a water/oil immersion objective with $20 \times$ magnification and an environmental cell culture chamber. Sequentially scanned images were collected at Ex/Em 495/510-550 nm for living cells and 530/610-650 nm for dead cells. Leica LAS AF and Leica LAS X software with a deconvolution module were used for image processing and fluorescence analysis, respectively.

\subsubsection{Apoptosis/Necrosis Assay}

The apoptosis/necrosis assay was performed by double staining with CellEvent Caspase 3/7-FITC (Thermo Fisher Scientific) and 7-aminoactinomycin D (BD Pharmigen) fluorescent dyes. Briefly, the cells $\left(4 \times 10^{5}\right)$ were seeded onto six-well plates and incubated until $70-80 \%$ confluency. On the next day, the cells were treated with $\beta$-carbolines in a final concentration of 5,10 , and $25 \mu \mathrm{M}$. Afterward, the cells were detached with trypsin (Thermo Fisher Scientific), washed twice with Dulbecco's Phosphate 
Buffered Saline (Thermo Fisher Scientific), and stained with fluorescent dyes for $30 \mathrm{~min}$ at $37^{\circ} \mathrm{C}$ in the dark, in line with the manufacturer's protocol. Cells were analyzed immediately with $488 \mathrm{~nm}$ excitation using an Accuri C6 flow cytometer (Becton Dickinson).

\subsubsection{Cell Cycle Analysis}

Next, $5 \times 10^{5}$ cells were seeded on six-well cell culture plates and incubated for $24 \mathrm{~h}$ with the compounds for analysis at a concentration of 5, 10, and $25 \mu \mathrm{M}$. After incubation, the cells were detached and washed as previously, and the cells were fixed with ice-cold $80 \%$ ethanol. After $1 \mathrm{~h}$ of incubation at $4{ }^{\circ} \mathrm{C}$, the cells were stored at $-20{ }^{\circ} \mathrm{C}$ for further analysis. Before analysis, the fixed cells were stained with propidium iodide (PI, $50 \mu \mathrm{g} / \mathrm{mL}$ ) with the addition of RNAse A $(100 \mu \mathrm{g} / \mathrm{mL})$ for $30 \mathrm{~min}$ at $37^{\circ} \mathrm{C}$ in the dark. PI fluorescence was measured using FACSCalibur (Becton Dickinson) and the data were analyzed using FlowJo software.

\subsubsection{Mitochondrial Membrane Potential $(\Delta \Psi \mathrm{m})$ Analysis}

The cells were seeded at a density of $4 \times 10^{5}$ onto six-well plates for flow cytometry, or at $1 \times 10^{4}$ per well on a glass-bottom ten-well CELLview slide (Greiner) for confocal microscopy, cultured at $37{ }^{\circ} \mathrm{C}$ and $5 \% \mathrm{CO}_{2}$ saturation, and incubated to $70-80 \%$ confluency. Subsequently, the cells were treated with 5, 10, and $25 \mu \mathrm{M}$ of $\mathrm{H}, \mathrm{NH}$, or $\mathrm{H} / \mathrm{NH}$ for $24 \mathrm{~h}$. For cytometric analysis, the cells were detached with trypsin (Sigma-Aldrich) and washed twice with DPBS (Thermo Fisher Scientific). Alterations in $\Delta \Psi \mathrm{m}$ were analyzed using the mitochondrial membrane potential sensitive dye 5,5',6,6' -tetrachloro-1,1',3,3' -tetraethylbenzimi-dazolylcarbocyanine iodide (JC-1, Thermo Fisher Scientific). Cells were stained with $2.5 \mu \mathrm{M} \mathrm{JC}-1$ for $30 \mathrm{~min}$ at $37^{\circ} \mathrm{C}$ in the dark. Immediately after staining, the cells were analyzed using an Accuri C6 flow cytometer (Becton Dickinson) at $488 \mathrm{~nm}$ excitation. For the confocal microscopy, the treated cells were stained directly on the CELLview Slides with $5 \mu \mathrm{M} \mathrm{JC}-1$ for $20 \mathrm{~min}$ in growth conditions, then washed twice and placed in FluoroBright DMEM. Live cell imaging was performed with a Leica TCS SP5 confocal laser scanning microscope using a water/oil immersion objective with $20 \times$ magnification and an environmental cell culture chamber. Images were collected at Ex/Em $514 / 529 \mathrm{~nm}( \pm 20)$ for J-aggregates (red fluorescence) and $585 / 590 \mathrm{~nm}( \pm 20)$ for JC-1 monomers (green fluorescence). Leica LAS AF and Leica LAS X software with a deconvolution module were used for image processing and fluorescence analysis, respectively. Untreated cells were used as a negative control, with $50 \mu \mathrm{M} \mathrm{CCCP} \mathrm{(carbonyl} \mathrm{cyanide} m$-chlorophenyl hydrazine) being applied to create a strong, single positive green fluorescence signal.

\subsubsection{Total RNA Isolation}

Total RNA was isolated using $1 \mathrm{~mL}$ of TRI Reagent solution (Thermo Fisher Scientific), following the manufacturer's protocol. RNA was obtained from the brain tissue of rats fed with chicory extract. Before RNA isolation, the brain tissue was homogenized for $1 \mathrm{~min}$ at $30 \mathrm{~Hz}$ using a TissueLyser II (Qiagen). DNA residue was removed with DNase I (DNA-free DNA Removal Kit, Thermo Fisher Scientific). The total RNA concentration was measured using a NanoDrop 2000 UV/Vis spectrophotometer at $260 \mathrm{~nm}$.

\subsection{8. cDNA Synthesis and Real-Time PCR}

Total RNA $(0.5 \mu \mathrm{g})$ was used for cDNA synthesis with the Transcriptor First-Strand cDNA Synthesis Kit (Roche), following the manufacturer's description, using oligo(dT) primers. Real-time PCR analysis was performed to assess expression levels of the BAX, BCL2, CASP3, CASP7, LRKK2, NDUFV2, PARK7 (DJ-1), PGC1, PINK1, PRKN (PARK2), SIRT1, SIRT2, SIRT3, SIRT6, SNCA, PRKN, and TAU (MAPT) genes. Each cDNA sample was analyzed using Mono Color Hydrolysis UPL Probes (Roche) selected for each gene using ProbeFinder Software (Roche). The PCR reactions were prepared in line with the manufacturer's protocol. PCR conditions for all genes were as follows: initial incubation step at $94{ }^{\circ} \mathrm{C}$ for $10 \mathrm{~min}$, followed by $40-45$ cycles of amplification $\left(15 \mathrm{~s}\right.$ at $94{ }^{\circ} \mathrm{C}, 30 \mathrm{~s}$ at $60{ }^{\circ} \mathrm{C}$, and $15 \mathrm{~s}$ at $72{ }^{\circ} \mathrm{C}$ ) (single acquisition), with a final cooling step at $40{ }^{\circ} \mathrm{C}$ for $2 \mathrm{~min}$. The analysis was performed 
using a LightCycler 480 II instrument (Roche). Relative gene expression was calculated using the Roche Applied Science E-Method and normalized to the reference genes PGK1, HPRT1, and G6PD. All standard curves were generated by amplifying a series of two-fold dilutions of cDNA. The primer sequences for the genes being analyzed and UPL (Universal ProbeLibrary, Roche) probes are shown in Table S1.

\subsection{Statistical Methods}

Behavioral tests and fecal analysis data were statistically analyzed using Statistica version 13.1 (StatSoft, Tulsa, OK, USA) and presented as means \pm standard deviations (SDs); statistical significance was set at $p<0.05$. A one-way ANOVA with Tukey's post hoc test was performed to determine whether there were significant differences. Statistical analysis of in vitro experiment was performed with an unpaired $t$-test using GraphPad Prism 8.00 for Windows. The results are presented as means \pm SDs obtained from 6-8 individuals (treated vs. control) and three independent experimental repeats for each one. Two-tailed $p$-values below 0.05 were considered significant.

\section{Results and Discussion}

One of the main features monitored in the animal experiment was the concentration of carbolines in the diet and the blood. The amount of carbolines in the diet was very low, at $0.13 \mu \mathrm{g} / \mathrm{g} \mathrm{H}$ and $0.04 \mu \mathrm{g} / \mathrm{g} \mathrm{NH}$. This is much less than in a coffee substitute such as chicory, which has $1.76 \mu \mathrm{g} / \mathrm{g} \mathrm{H}$ and $2.90 \mu \mathrm{g} / \mathrm{g} \mathrm{NH}$ [21]. Thus, the addition of coffee substitute to the animal diet may increase the concentration of carbolines in the diet.

The in vivo experiment was designed keeping in mind the data from the preliminary in vitro studies with the human spontaneously immortalized keratinocyte cell line (HaCaT), which did not show any toxic effect of $\beta$-carbolines in examined range of concentrations, $\mathrm{IC}_{50}>100 \mu \mathrm{M}$ (Figure S1).

We did not observe any effects of the diet on the water, protein, fat, dietary fiber, and ash content of the rats' feces (Table S2). The average weight gain of rats during the trial ( $58 \mathrm{~g})$, and the amount of the diet consumed (about $32 \mathrm{~g} /$ day) during the experiment, did not differ between the control and experimental groups. This suggests that there was no negative effect on the general health of the animals associated with the addition of carbolines to the diet.

After fourteen weeks of the experiment, the concentration of $\beta$-carbolines in the animals' plasma was measured. These data are presented as concentrations of $\mathrm{H}$ and $\mathrm{NH}$ in the animals' blood (Table 1). It can be seen that the level of carbolines in plasma increased with increasing amounts of $\mathrm{H}$ or $\mathrm{NH}$ in the experimental diet. Taking into account the level of both carbolines in the control diet without carboline additions, $\mathrm{H}$ increased by a factor of about four at the greatest addition, while $\mathrm{NH}$ increased two-fold at the greatest addition; however, the final concentration of $\mathrm{NH}$ was greater than $\mathrm{H}$, as is typical of natural products [13].

Table 1. Contents of harman $(\mathrm{H})$ and norharman $(\mathrm{NH})$ in animal blood: stage I and II (ng/mL).

\begin{tabular}{ccccc}
\hline Animal Group & Harman $(\mathbf{n g} / \mathbf{m L})$ & SD & Norharman $(\mathbf{n g} / \mathbf{m L})$ & SD \\
\hline \multicolumn{5}{c}{ Stage I } \\
\hline C & 0.020 & 0.003 & 0.060 & 0.004 \\
H1 & 0.038 & 0.004 & 0.049 & 0.006 \\
H2 & 0.052 & 0.010 & 0.054 & 0.011 \\
H3 & 0.084 & 0.009 & 0.046 & 0.005 \\
NH1 & 0.018 & 0.008 & 0.080 & 0.039 \\
NH2 & 0.021 & 0.010 & 0.089 & 0.022 \\
NH3 & 0.018 & 0.005 & \multicolumn{3}{c}{0.007} \\
C & 0.010 & 0.001 & 0.067 & 0.014 \\
\hline CS & 0.016 & 0.004 & 0.110 & \\
\hline
\end{tabular}

Stage I: LOD (limit of detection): $\mathrm{H}(0.013 \mathrm{ng} / \mathrm{mL}), \mathrm{NH}(0.067 \mathrm{ng} / \mathrm{mL}) ; \mathrm{LOQ}$ (limit of quantification): $\mathrm{H}(0.026 \mathrm{ng} / \mathrm{mL})$, $\mathrm{NH}(0.137 \mathrm{ng} / \mathrm{mL}) ; \mathrm{C}=$ control; $\mathrm{H} 1=10 \mu \mathrm{g} \mathrm{H} / \mathrm{kg}$ of exp. diet, $\mathrm{H} 2=15 \mu \mathrm{g} \mathrm{H} / \mathrm{kg}$ of exp. diet; $\mathrm{H} 3=20 \mu \mathrm{g} \mathrm{H} / \mathrm{kg}$ of exp. diet; $\mathrm{NH} 1=8 \mu \mathrm{g} \mathrm{NH} / \mathrm{kg}$ of exp. diet, $\mathrm{NH} 2=12 \mu \mathrm{g} \mathrm{NH} / \mathrm{kg} ; \mathrm{NH} 3=16 \mu \mathrm{g} \mathrm{NH} / \mathrm{kg}$. Stage II: LOD: H $(0.009 \mathrm{ng} / \mathrm{mL})$, $\mathrm{NH}(0.044 \mathrm{ng} / \mathrm{mL})$; LOQ: H $(0.018 \mathrm{ng} / \mathrm{mL}), \mathrm{NH}(0.088 \mathrm{ng} / \mathrm{mL}) ; \mathrm{C}=$ control; $\mathrm{CS}=12.5 \mathrm{~g}$ of chicory $/ \mathrm{kg}$ of exp. diet. Number of animals in all groups $n=6$. 
Despite the above, the battery of behavioral tests in the first stage of the experiment did not reveal any statistically significant differences in animal activity; however, we did note some positive animal reactions in the Porsolt test (Figure 1), where animals supplemented with carbolines displayed more frequent head movements than those in the control group. Moreover, the rats that received the lowest amounts of $\mathrm{H}$ and $\mathrm{NH}$ were more mobile than the control animals, than the rats fed greater amounts of $\beta$-carbolines. The behavioral effects induced by $\beta$-carbolines observed in our rats are in agreement with the literature data, which supports the antidepressant action of those compounds. For example, in the study of Farzin and Mansouri [8], treatment with carbolines reduced the immobility time in the forced swimming test.

(a)

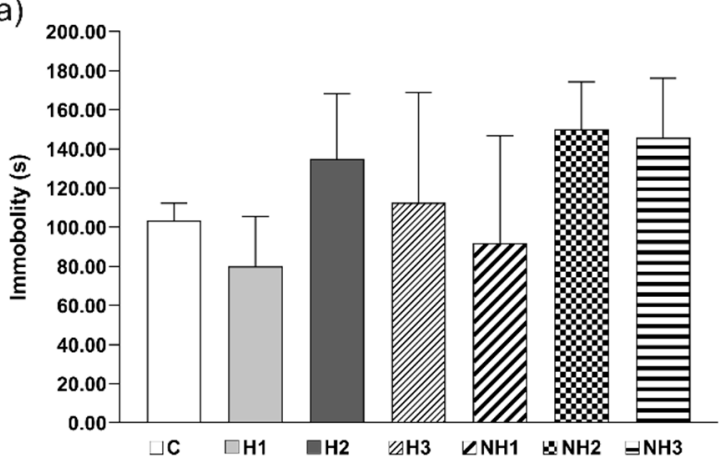

(c)

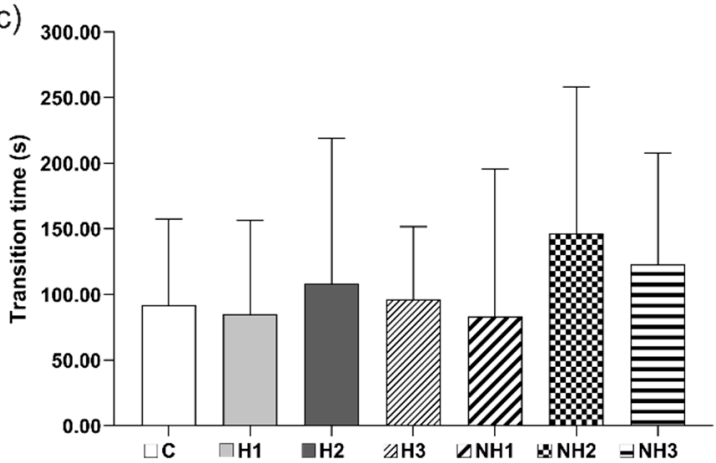

(b)

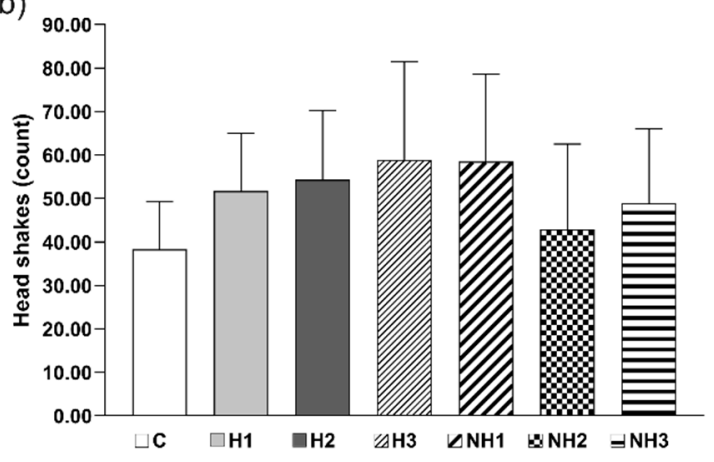

Figure 1. Behavioral tests: (a) Porsolt test: mean time of immobility, (b) Porsolt test: mean number of head shaking, (c) orientation and spatial memory test: mean time transition through the maze. Samples: $\mathrm{C}=$ control, $\mathrm{H} 1=10 \mu \mathrm{g} \mathrm{H} / \mathrm{kg}, \mathrm{H} 2=15 \mu \mathrm{g} \mathrm{H} / \mathrm{kg}, \mathrm{H} 3=20 \mu \mathrm{g} \mathrm{H} / \mathrm{kg}, \mathrm{NH} 1=8 \mu \mathrm{g} \mathrm{NH} / \mathrm{kg}, \mathrm{NH} 2=12 \mu \mathrm{g}$ $\mathrm{NH} / \mathrm{kg}, \mathrm{NH} 3=16 \mu \mathrm{g} \mathrm{NH} / \mathrm{kg}$. Number of animals in all groups $n=6$.

Studies on human cell lines were also undertaken to show the effects of $\beta$-carbolines on cell viability and intracellular processes. The effect of $\mathrm{H}$ and $\mathrm{NH}$ was examined using aged normal human cells (MRC-5 fibroblasts, ATCC, passage 17-20) and cells isolated from a patient with Parkinson's disease (AG20445 fibroblasts, Coriell). Since immortalized cells often exhibit cancer cell characteristics, the $\mathrm{HaCaT}$ cell line used in the preliminary analysis was excluded from further studies.

To determine the viability of the treated cells, we performed real-time cell proliferation analysis using the xCELLigence system, which allows continuous intravital analysis of adherent cell cultures [22]. Changes in the impedance directly proportional to the proliferation rate (viability) were monitored during cell culturing in the presence of $\mathrm{H}, \mathrm{NH}$, or $\mathrm{H} / \mathrm{NH}$ at final concentrations of $1,5,10,25,50$, and $100 \mu \mathrm{M}$.

We found out that, in the low concentration range $(1-25 \mu \mathrm{M})$, neither $\mathrm{H}$ nor $\mathrm{NH}$ showed any cytotoxic effect on the MRC- 5 cell line. Moreover, $24 \mathrm{~h}$ after the administration of both compounds, we noted a significant increase in the cell proliferation rate, as compared to the control, and this effect was observed throughout the experiment (Figure 2a). 
(a)
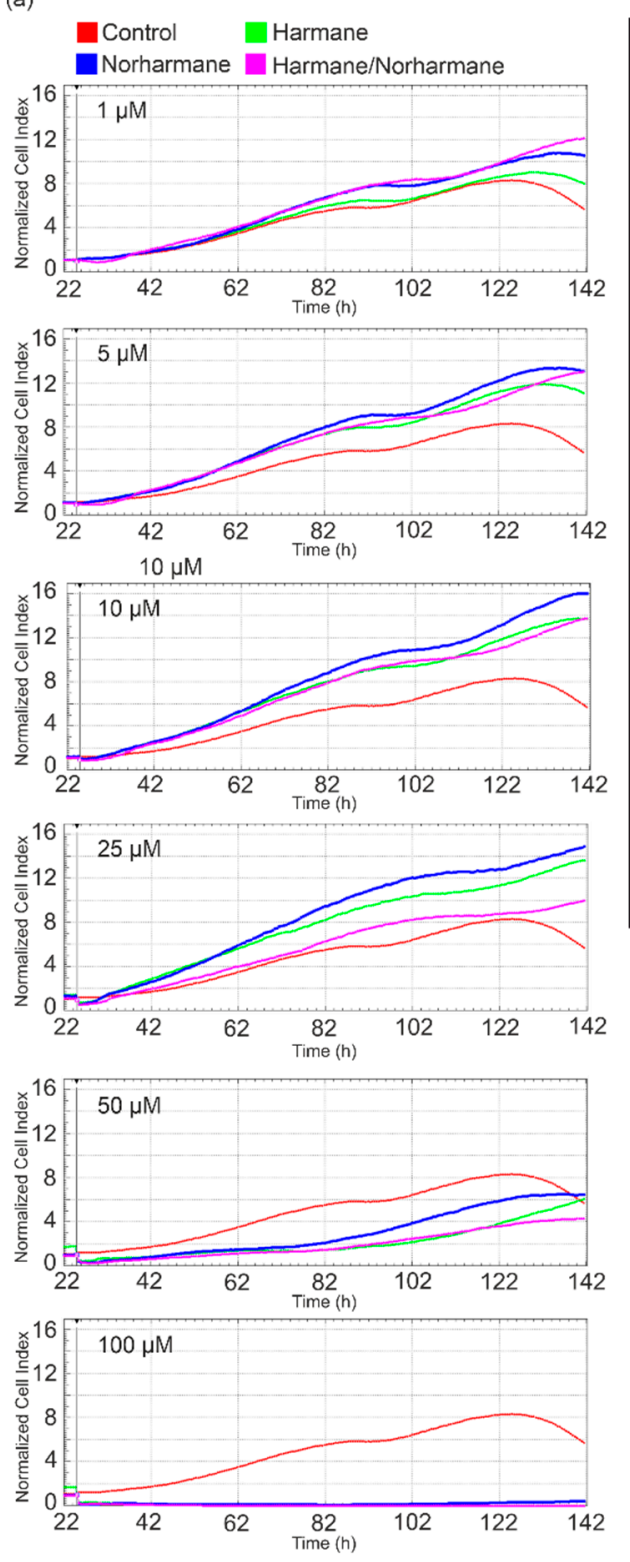

(b)

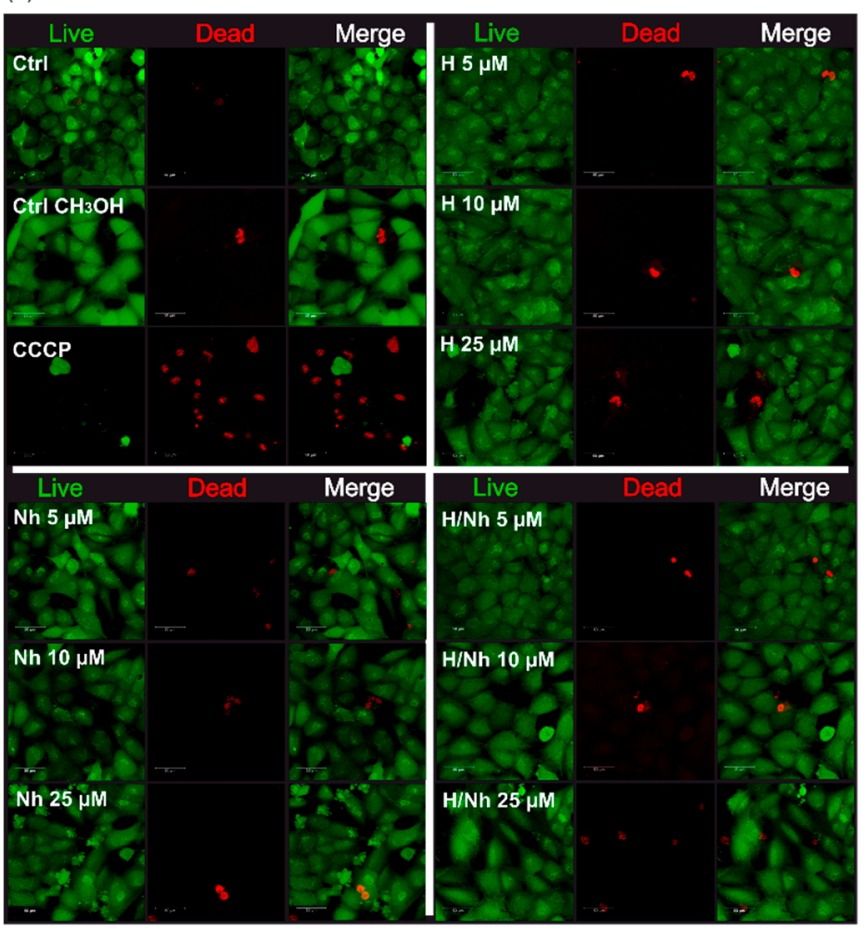

(c)

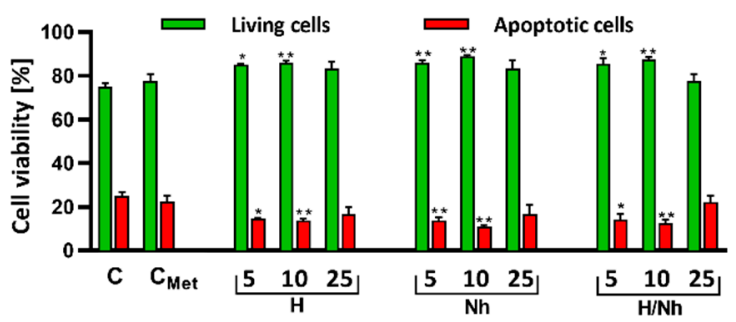

(d)

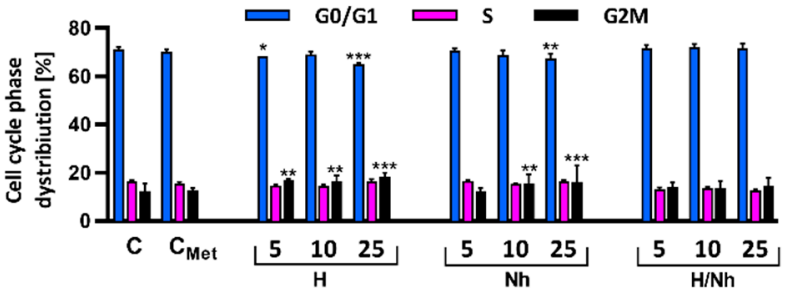

Figure 2. Viability analysis of aged human cells after harman and norharman treatment. (a) Real-time analysis of MRC- 5 cells (passage 19, aged cells) proliferation by the xCELLigence system for 6 days in the presence of $1,5,10,25,50$, and $100 \mu \mathrm{M}$ harmane $(\mathrm{H})$, norharmane $(\mathrm{NH})$ or a mix of both $(\mathrm{H} / \mathrm{NH})$. Proliferation was monitored in $30 \mathrm{~min}$ intervals. Vertical lines on the graphs indicate the time points for adding compounds. Normalized Cell Index $(\mathrm{NCI})=\mathrm{CI}_{\text {original }} / \mathrm{CI}_{\text {normalize time }}$ (b) Confocal microscopy analysis of MRC-5 viability using LIVE/DEAD assay kit. Panels with green (Ex/Em 495/515 nm) and red fluorescence (Ex/Em 530/635 m) show live and dead cells, respectively. Merged images are presented on the right panel. (c) Flow cytometry analysis of apoptosis in MRC-5 cells treated with 5, 10, and $25 \mu \mathrm{M}$ after $24 \mathrm{~h}$ with Casp 3/7-FITC/7-AAD dual staining. (d) Flow cytometry analysis of $\mathrm{H}, \mathrm{NH}$, and $\mathrm{H} / \mathrm{NH}$ effect $(5,10$, and $25 \mu \mathrm{M})$ of on the cell cycle phase distribution in MRC-5 cells after $24 \mathrm{~h}$. The data are presented as the mean \pm SEM (standard error of the mean) from three independent experiments. Statistical significance (ANOVA): $\left({ }^{*}\right) p<0.05,\left({ }^{* *}\right) p<0.01,\left({ }^{* * *}\right) p<0.001$.

The greatest proliferation rate was obtained for the $\mathrm{NH}$ and $\mathrm{H} / \mathrm{NH}$ mix used at final concentrations of 1,5 , and $10 \mu \mathrm{M}$. For $25 \mu \mathrm{M}$ of $\mathrm{H} / \mathrm{NH}$ mix, a significant decrease in the proliferation level was observed compared to the results received for $\mathrm{H}$ or $\mathrm{NH}$, used separately, and remained on the control cell level. 
A toxic effect of the $\beta$-carbolines was noted at a concentration of $50 \mu \mathrm{M}$, where the proliferation of MRC- 5 was reduced by approximately $50 \%$. However, concentrations of $100 \mu \mathrm{M}$ and higher completely inhibited cell growth under experimental conditions. A similar effect was obtained for AG20445 (PD cells) (Figure S2a). A significant increase in CI values was noted $24 \mathrm{~h}$ after treatment with the range of $1-50 \mu \mathrm{M}$ of $\mathrm{H}, \mathrm{NH}$, and $\mathrm{H} / \mathrm{NH}$. Over the next $24 \mathrm{~h}$, the proliferation rate remained at the same level in these concentrations. However, an opposite effect was observed for $50 \mu \mathrm{M}$ of the $\mathrm{H} / \mathrm{NH}$ mix, where the proliferation rate decreased below the level of control cells. We found that total inhibition of AG20445 proliferation occurred at concentrations above $100 \mu \mathrm{M}$, as was observed for MRC- 5 cells. In other studies, the cytotoxicity of natural carbolines and their modified synthetic analogs was analyzed in other cell lines, especially of tumor origin, to investigate their anticancer activity [23-25]. Previous results reported for harman, expressed as $\mathrm{ED}_{50}$ values (effective dose for $50 \%$ of the population), were determined for tumor cell lines, including KB, A549, CAKI-1, MCF-7, IA9, SK-MEL-2, and U-87-MG as well as HEL and were 8.9, 9.3, 8.0, 19.0, 6.1, $>20,19.0$, and $9.8 \mu \mathrm{g} / \mathrm{mL}$, respectively [25]. The $50 \%$ decrease in MRC- 5 cell viability at a concentration of $\sim 50 \mu \mathrm{M}$, which corresponds to $9.11 \mu \mathrm{g} / \mathrm{mL}$ (harman) and $8.41 \mu \mathrm{g} / \mathrm{mL}$ (norharman), is a result comparable to previous ones. It was shown in anticancer studies that modification of $\beta$-carboline alkaloids could impact an increase of their cytotoxicity [23-25].

In the next step, we performed flow cytometric analysis of cell apoptosis after $24 \mathrm{~h}$ of incubation in the presence of $\mathrm{H}, \mathrm{NH}$, and $\mathrm{H} / \mathrm{NH}(5,10$, and $25 \mu \mathrm{M})$ (Figure $2 \mathrm{c}$ and Figure S2b). We showed that these compounds do not induce apoptosis under the experimental conditions. Furthermore, the $\beta$-carbolines led to an increase in the percentage of live cells, as compared to the untreated cells, especially at the final concentrations of 5 and $10 \mu \mathrm{M}$ (Figure 2c and Figure S2b). These results were confirmed by confocal microscopy analysis using a live/dead fluorescent test (Figure 2b). In the previous research, Hamman et al. [26] demonstrated that synthetic methylated derivative of norharman (i.e., 9-methyl- $\beta$-carboline (9-me-BC)), discovered as a neuroprotective compound, reduced the number of necrotic cells in the primary mesencephalic dopaminergic cell culture derived from embryonic mice as a model with relevance to Parkinson's disease, which corresponds to our results. Moreover, 9-me-BC was identified as an agent capable of increasing the number of dopaminergic neurons in a concentration-dependent manner while maintaining the functionality of these neurons $[26,27]$. On the other hand, dimethyl $\beta$-carboline derivatives (2,9-dimethyl-BC) exert highly toxic effects not only on dopaminergic neurons but also on other cell constituents in primary dopaminergic culture [28].

Cytometric analysis of DNA content in cells treated with 5, 10, and $25 \mu \mathrm{M}$ of $\mathrm{H}, \mathrm{NH}$, or $\mathrm{H} / \mathrm{NH}$ allowed us to assess their effect on the cell cycle. We found that these compounds regulate the cell cycle of both the aged MRC-5 and AG20445 cells. We noted an increase in the percentage of cells in G2M phase after $\beta$-carboline treatment (Figure $2 \mathrm{~d}$ and Figure S2c). The G2 phase prepares the cells for the mitosis process, which occurs in the M phase [29]. The results of the cell cycle analysis correlate with data from the cell viability analysis and may explain the increased percentage of live cells in the apoptosis test.

The effects of $\mathrm{H}$ and $\mathrm{NH}$ on mitochondrial redox state were also investigated. One factor associated with aging and the progression of certain cell neurodegenerative changes is a chronic state of oxidative stress [30]. The mitochondria play a crucial role in cell viability. Alterations in their activity affect the function, metabolism, and the lifespan of cells [31]. Fundamental cellular functions, such as ATP generation, $\mathrm{Ca}^{2+}$ uptake and storage, and the generation and detoxification of reactive oxygen species (ROS), are driven by the mitochondrial membrane potential $(\Delta \Psi \mathrm{m})$. This parameter is a reliable measure of cell stress and apoptosis [32]. We evaluated the mitochondrial redox state of MRC-5 and AG20445 cells after $24 \mathrm{~h}$ incubation with 5, 10, and $25 \mu \mathrm{M}$ of $\mathrm{H}, \mathrm{NH}$, and $\mathrm{H} / \mathrm{NH}$ using confocal microscopy and flow cytometry (Figure 3 and Figure S3). 
(a)

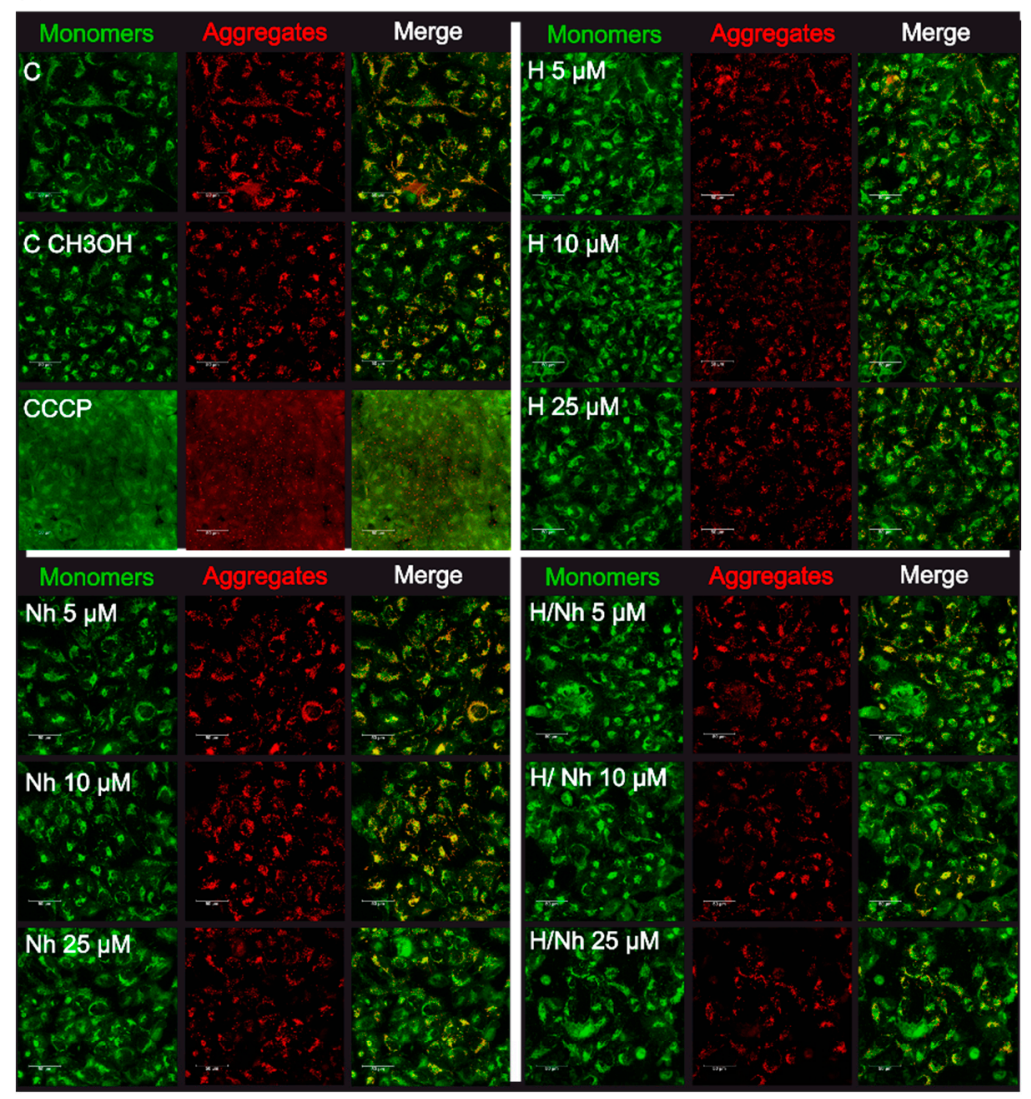

(b)

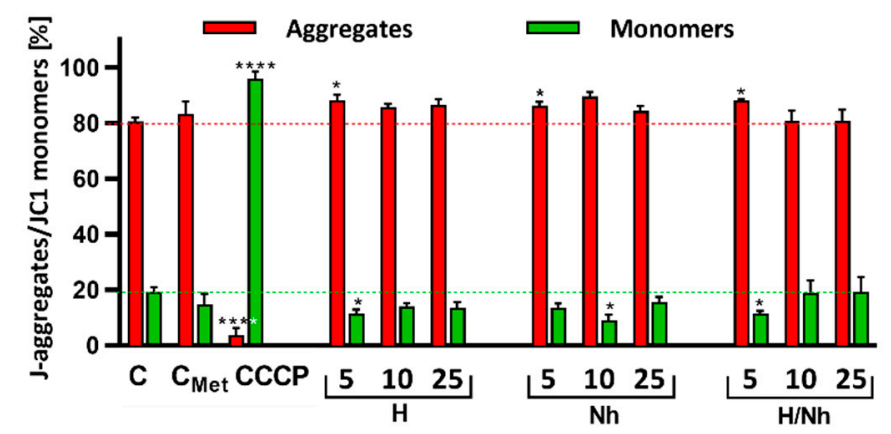

Figure 3. Mitochondrial oxidative stress analysis after harmane and norharmane treatment. (a) Confocal microscopy analysis of the mitochondrial membrane status in MRC-5 after $24 \mathrm{~h}$ of harmane $(\mathrm{H})$, norharmane $(\mathrm{NH})$, and mix of both $(\mathrm{H} / \mathrm{NH})$ treatment $(5,10$, and $25 \mu \mathrm{M})$ determined by JC- 1 staining. Left panels show JC-1 monomers (green fluorescence, Ex/Em 485/530 nm) which indicate a decrease of mitochondrial potential and the middle panels present the J-aggregates (red fluorescence, Ex/Em $535 / 590 \mathrm{~nm}$ ) which indicate high membrane potential. Merged images are on the right panels. (b) Flow cytometry analysis of changes in the mitochondrial membrane potential $(\Psi \mathrm{m})$. The fluorescence intensity histograms are representative of three independent experiments, whereas the bar graphs represent the mean fluorescence intensity \pm SEM. Statistical significance (ANOVA): $\left(^{*}\right) p<0.05,\left({ }^{* *}\right) p<0.01$, $\left.{ }^{* * *}\right) p<0.001,\left({ }^{* * *}\right) p<0.0001$. CCCP $(50 \mu \mathrm{M})$ was used as a positive control to decrease $\Psi \mathrm{m}$.

For this purpose, cells were stained with JC-1 cationic carbocyanine dye. We demonstrated that both $\beta$-carbolines improved the energetic state of the cells under experimental conditions, as seen by the increasing percentage of cells with high $\Delta \Psi \mathrm{m}$ in the study population, as compared with the control (Figure $3 b$ and Figure $\mathrm{S} 3 \mathrm{~b}$ ). This result indicates the good physiological condition of the treated cells and shows that $\beta$-carbolines do not affect mitochondrial ROS production. Furthermore, the improved energetic state of the treated cells may suggest the antioxidant effects of analyzed 
$\beta$-carbolines used in low concentrations (Figure $3 b$ and Figure S3b). The antioxidative action of $\beta$-carbolines, whether natural or synthetic, against reactive forms of oxygen has been demonstrated in the study of Lehmann [33]; there is no other evidence in the literature concerning this aspect of neurodegenerative protection. However, it was shown that harman and its derivatives have a significant protective effect against $\mathrm{H}_{2} \mathrm{O}_{2}$ and paraquat oxidative agents in yeast and mammalian cells, and that their ability to scavenge hydroxyl radicals contributes to their antimutagenic and antigenotoxic effects [34]. Moreover, $\beta$-carboline alkaloids activated expression of the antioxidant enzymes superoxide dismutase (SOD) and glutathione peroxidase (GSH-px) and suppressed the formation of maleic dialdehyde (MDA) in the cortex of mice with induced dementia and improved the ability of antioxidant defense, indicating their neuroprotective effects [35]. Nevertheless, other studies have shown that a dimethylated $\beta$-carboline derivative such as 2,9-dimethyl-BC increased free radical production, decreased respiratory activity and mitochondrial membrane potential as well as ATP content, contributing to the apoptotic mode of cell death [28].

Two groups of animals were used in stage 2 of the in vivo experiment: one group received the control diet, and the second received the experimental diet enriched with coffee substitute (chicory), and with the $\beta$-carboline quantities matched to the quantities found in two cups of chicory coffee, as might be consumed daily by humans. We chose a two-cup dose on account of the positive observation made in the first stage of the experiment for the lowest doses of carbolines, as well as suggestion from in vitro studies done in parallel, as described above. The main concept of stage 2 of the experiment was to use a natural source of $\beta$-carbolines in the diet and to observe its effect on the rats' behavior. The richest natural source of $\beta$-carbolines is coffee and its substitutes. In our previous studies [16], we noted that roasted artichoke contained very significant levels of carbolines, and we proposed a mixture of chicory and artichoke to give the highest possible concentration of $\beta$-carbolines in coffee substitute. However, we ultimately omitted the artichoke as we found it contains relatively high levels of some toxic compounds, particularly of acrylamide [21]. During the experiment, the body weight of the rats and the amount of diet they consumed were monitored; they proved to be similar in both groups. Various nutritional parameters determined from the feces also did not differ (Table S2). After fourteen weeks of the experiment, the concentration of carbolines in the animals' blood was measured using the method described in Section 2 and presented in Table 1. The literature does not have much data on the level of carbolines in blood. Our data confirmed the natural presence of $\beta$-carbolines in the control samples. The level of NH in the experimental animals' blood samples was about three times higher than that of $\mathrm{H}$ (by comparison, $\mathrm{NH}$ and $\mathrm{H}$ occurred at 0.060 and $0.020 \mathrm{ng} / \mathrm{mL}$, respectively in the control). The concentration of both carbolines was higher in the plasma of rats receiving a diet enriched with coffee substitutes than in the control group.

$\mathrm{Li}$ et al. [9] found significantly higher levels of $\beta$-carbolines in rat blood than in our experiment; however, the procedures in the experiments differed greatly and the results are thus almost impossible to compare. In our experiment, the samples of blood were taken after feeding period, in which the experimental diet provided a constant supply of carbolines, while in the study of Li et al. [9] the carbolines were administered either orally or by intravenous injection, and plasma was taken intravitally. Li et al. [9] showed how the large quantity of carbolines injected into the animal decreased rapidly in the plasma over just a few hours; however, they were using very large doses of the size employed in drug therapy: the level of $\mathrm{H}$ in the plasma was initially about $1000 \mathrm{mg} / \mathrm{mL}$, and immediately decreased. In our experiment, carboline levels in plasma must obviously have decreased, but we made use of small doses that could be taken in as part of the everyday diet. The measurements of carboline levels in the blood, and their proportional growth in parallel with their growth in the diet is only evidence of the metabolizing of these compounds after eating. Taking into account the average body mass of animals, their average feed consumption, and the concentration of carbolines in the feed, only about $0.15 \%$ of the $\mathrm{H}$ and about $0.5 \%$ of $\mathrm{NH}$ taken in was found in the blood. This led to a small increase in the level of carbolines in the rats' blood, which nonetheless apparently sufficed to affect the rats' behavior. As compared with the level of carbolines in human blood, which was $4.1 \pm 9 \mathrm{pg} / \mathrm{mL}$ for 
$\mathrm{H}$ and $4.9 \pm 7.9 \mathrm{pg} / \mathrm{mL}$ for $\mathrm{NH}$ [36], or in other papers for norharman $26.9 \pm 10.7 \mathrm{pg} / \mathrm{mL}$ [37], our values were different, though of a similar magnitude.

The activity of the animals, as measured by the series of behavioral tests, is presented in Figure 4 . It can be seen from the data that the addition of the coffee substitute to the animal diet made the rats more active; in this case, all the observations from behavioral tests were statistically significant. This may suggest a possible positive effect of carbolines in the diet on animal behavior pattern. In all the behavioral experiments, it was seen that ingestion of a diet enriched with coffee substitute reduced immobility time during FST and transition time via labyrinth, while increasing mobility time, time spent in the center, and frequencies of vertical movements and self-grooming of rats during OFT. It should thus be highlighted that this is the first paper to describe a positive effect of carbolines from coffee substitute on the behavioral pattern of rodents. It is also important to mention, as in stage 1 , the tested diet had no adverse effects on body weight or fecal parameters. In previous research Gruss et al. [38] demonstrated that synthetic methylated derivative of harmane (9-me-BC) acts as a cognitive enhancer in a hippocampus-dependent task. Treatment of rats with 9-me-BC showed significantly accelerated acquisition compared with controls. It was concluded that the behavioral effects may be associated with a stimulatory impact on hippocampal dopamine levels and dendritic and synaptic proliferation.

The data from both stages show that increasing amounts of $\beta$-carbolines in the animal diet were reflected in their increasing concentrations in the blood, as measured after fourteen weeks of the experiments. It is worth underlining that the amount of carbolines added to the diet was very low in comparison to that reported by other authors [9]. However, stage 1 of the experiment gave no real evidence of any effect of these additions on animal activity. Further studies are needed to explain this; currently, we can only suggest that this is due to the natural origin of the $\beta$-carbolines used in stage 2 , or the occurrence of both carbolines in the diet. In stage 1 of the animal experiment, they were used as individual, standard chemical components.

We also examined the effect of $\beta$-carbolines on the expression level of selected genes associated with aging, apoptosis, and neurodegenerative diseases (including Parkinson's) in the brain tissue derived from rats fed chicory extract as a source of natural $\beta$-carbolines. Expression levels were determined using real-time PCR (Figure 5). The genes we examined were of three types: apoptotic genes (caspase 3, 7, BAX, BCL2), whose expressions are associated with biochemical processes leading to cell death [39]; genes involved in delaying aging processes and protecting the cell from various types of stress, such as oxidative stress, as well as those involved in DNA repair processes (SIRT1, 2, 3 and 6 , PGC-1 $\alpha$, PINK1) [30,40,41]; and genes associated with neurodegenerative diseases, such as LRKK2, SYNC, PARK7 (DJ-1), PRKN (PARK2), and TAU [42,43]. 
(a)

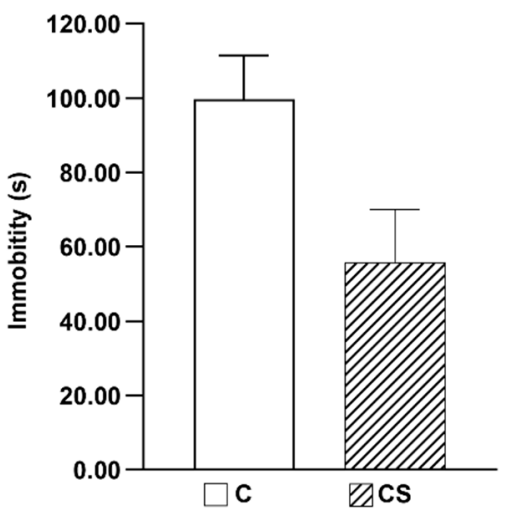

(c)

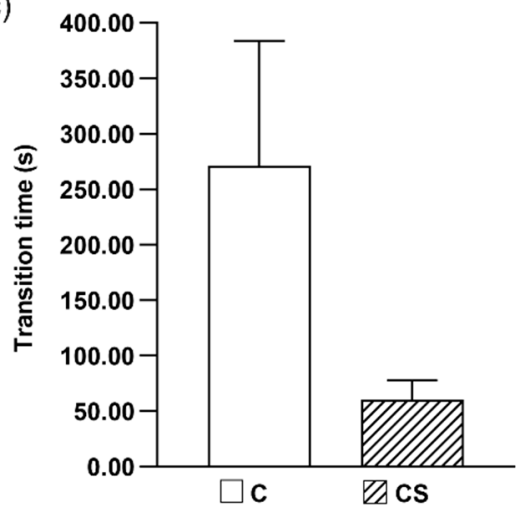

(e)

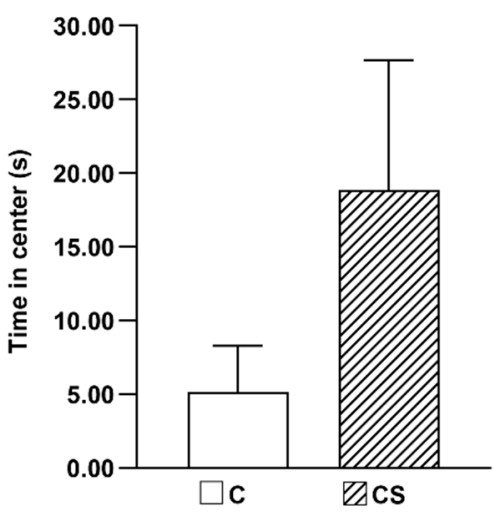

(g)

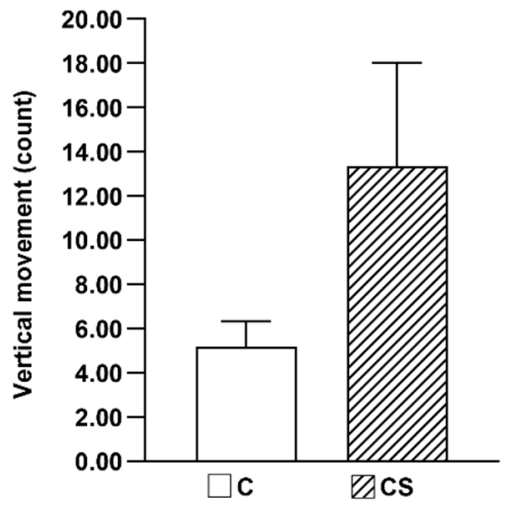

(b)

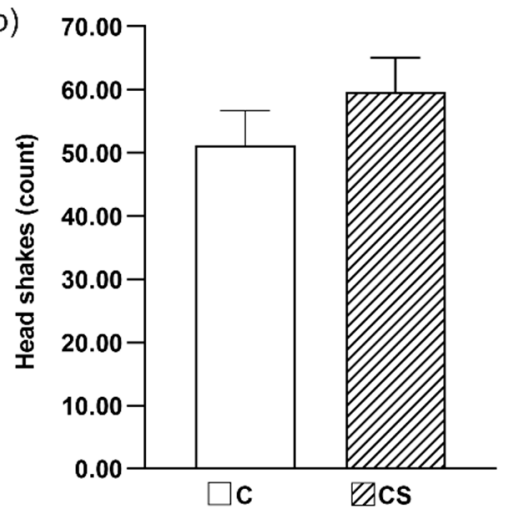

(d)

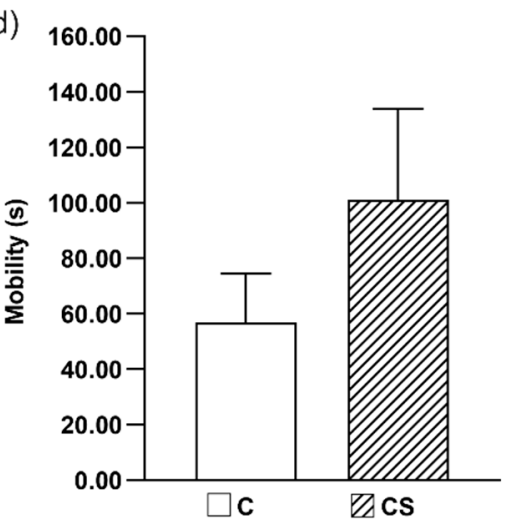

(f)

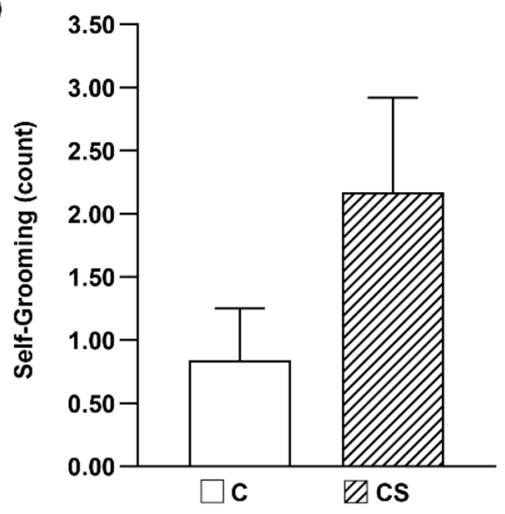

Figure 4. The battery of behavioral tests: (a) Porsolt test: mean time of immobility, (b) Porsolt test: mean number of head shaking, (c) classical labyrinth test: mean time transition through the labyrinth, (d) open field test (OFT): mean time of mobility, (e) OFT: mean time in center, (f) OFT: mean number of self-grooming (facial wash, body cleaning, genital grooming), (g) OFT: mean number of vertical movement. $\mathrm{C}=$ control group, $\mathrm{CS}=$ group with $12.5 \mathrm{~g}$ of chicory $/ \mathrm{kg}$ of exp. diet. Number of animals in all groups $n=6$. 
a)
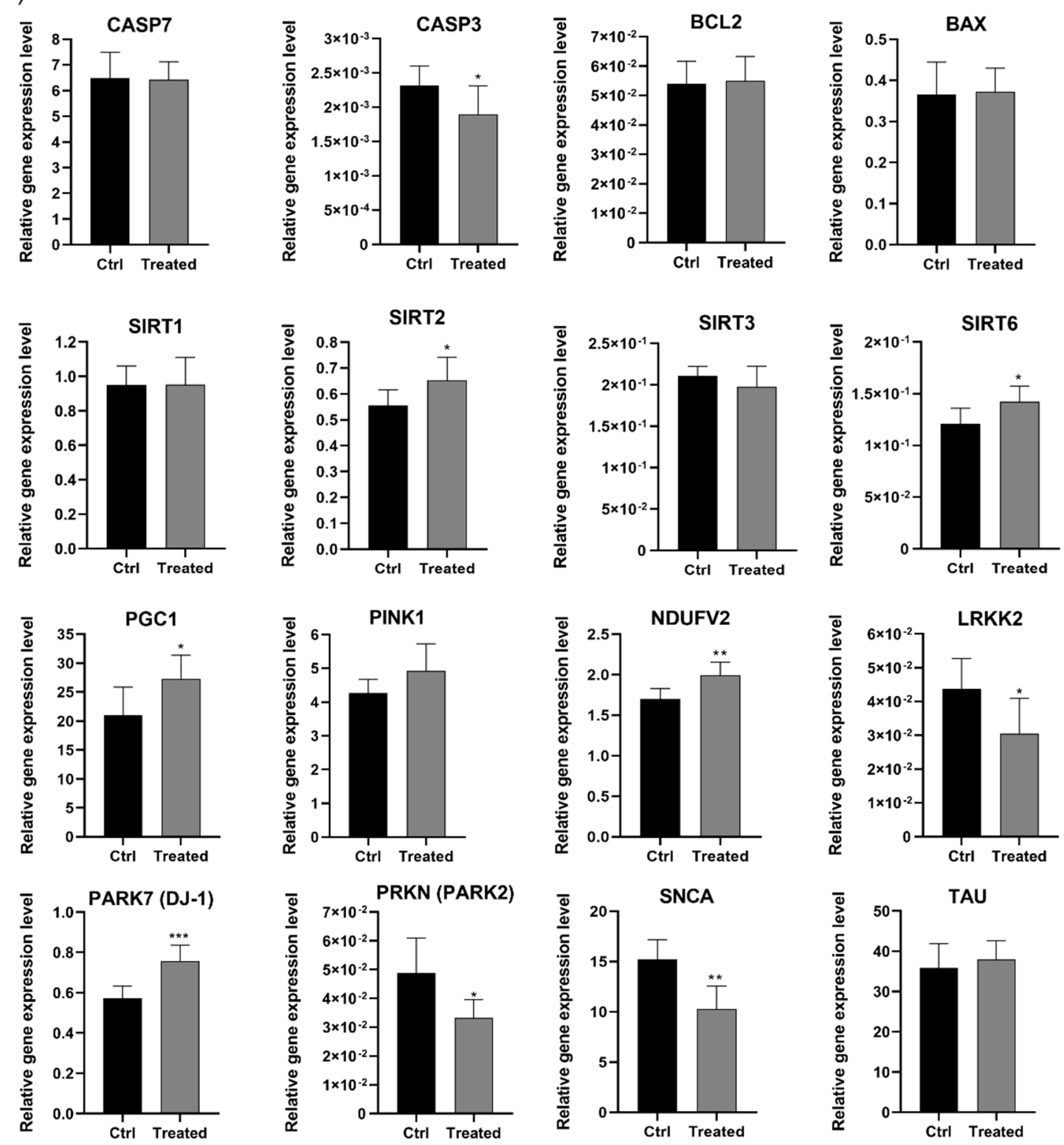

Figure 5. Cont. 
(b)

\begin{tabular}{|c|c|c|c|c|}
\hline Cellular Pathway & Gene & Full Gene Name & $\begin{array}{l}\text { Changes in } \\
\text { Expression } \\
\text { Level }\end{array}$ & Function of Encoded Protein \\
\hline \multirow{4}{*}{ Apoptosis } & CASP3 & Caspase 3 & $\downarrow$ & \multirow{4}{*}{$\begin{array}{l}\text { Associated with biochemical } \\
\text { processes leading to cell death }\end{array}$} \\
\hline & CASP7 & Caspase 7 & no change & \\
\hline & $B C L-2$ & $\begin{array}{l}\text { B-Cell CLL/Lymphoma 2, } \\
\text { Apoptosis Regulator }\end{array}$ & no change & \\
\hline & $B A X$ & BCL2 Associated X Protein & no change & \\
\hline \multirow{6}{*}{ Aging } & SIRT1 & Sirtuin 1 & no change & \multirow{6}{*}{$\begin{array}{l}\text { Delaying aging processes, } \\
\text { protection against various } \\
\text { types of cellular stress (e.g., } \\
\text { oxidative stress), DNA repair }\end{array}$} \\
\hline & SIRT2 & Sirtuin 2 & $\uparrow$ & \\
\hline & SIRT3 & Sirtuin 3 & no change & \\
\hline & SIRT6 & Sirtuin 6 & $\uparrow$ & \\
\hline & PGC-1 & $\begin{array}{l}\text { PPARG Coactivator } 1 \\
\text { Alpha }\end{array}$ & $\uparrow$ & \\
\hline & PINK1 & PTEN Induced Kinase 1 & $\uparrow$ & \\
\hline \multirow{6}{*}{$\begin{array}{l}\text { Neurodegenerative } \\
\text { changes }\end{array}$} & NDUF2 & $\begin{array}{l}\text { NADH: Ubiquinone } \\
\text { Oxidoreductase Core } \\
\text { Subunit V2 }\end{array}$ & $\uparrow$ & $\begin{array}{c}\text { Mitochondrial respiratory } \\
\text { chain element, mutated form } \\
\text { is associated with Parkinson's } \\
\text { disease (PD) }\end{array}$ \\
\hline & LRKK2 & $\begin{array}{c}\text { Leucine Rich Repeat } \\
\text { Kinase } 2\end{array}$ & $\downarrow$ & $\begin{array}{c}\text { Dysfunction of LRRK2 may } \\
\text { affect the accumulation of } \\
\alpha \text {-synuclein, associated with } \\
\text { PD }\end{array}$ \\
\hline & $\begin{array}{l}\text { PARK7 } \\
(D J-1)\end{array}$ & $\begin{array}{c}\text { Parkinsonism Associated } \\
\text { Deglycase }\end{array}$ & $\uparrow$ & $\begin{array}{l}\text { Wild-type PARK7 is } \\
\text { implicated in antioxidant } \\
\text { activity, modulation of } \\
\text { transcription, and } \\
\text { chaperone-like functions }\end{array}$ \\
\hline & $\begin{array}{c}\text { PRKN } \\
(\text { PARK2) }\end{array}$ & $\begin{array}{l}\text { Parkin RBR E3 Ubiquitin } \\
\text { Protein Ligase }\end{array}$ & $\downarrow$ & $\begin{array}{c}\text { Dysfunction of LRRK2 affects } \\
\text { the accumulation of } \\
\alpha \text {-synuclein, associated with } \\
\text { PD }\end{array}$ \\
\hline & SNCA & Synuclein Alpha & $\downarrow$ & $\begin{array}{l}\text { Mutated form } \alpha \text {-synuclein } \\
\text { and an excess of wild-type } \\
\text { cause PD }\end{array}$ \\
\hline & $\begin{array}{c}\text { TAU } \\
(\text { MAPT) }\end{array}$ & $\begin{array}{l}\text { Microtubule-associated } \\
\text { protein tau }\end{array}$ & no change & $\begin{array}{l}\text { Involved in microtubule } \\
\text { stabilization, membrane } \\
\text { binding, and regulation of } \\
\text { axon transport, dysfunction } \\
\text { associated with PD and } \\
\text { Alzheimer's disease (AD) }\end{array}$ \\
\hline
\end{tabular}

Figure 5. The expression level of selected genes in the brain tissue of aged rats fed with chicory extract-enriched feed. (a) Relative real-time PCR analysis of pro-apoptotic genes (CASP3, CASP7, BAX, BCL2), genes involved in delaying aging processes, different cellular type of stress, as well as DNA repair processes (SIRT1, SIRT2, SIRT3, SIRT6, PINK1, PGC1), and genes associated with neurodegenerative diseases (SYNC, LRKK2, PARK7, PRKN, TAU). The results are presented as the mean \pm SD obtained from 6-8 individuals (treated vs. control) and three independent experimental repeats for each one. Statistical significance $(t$-test). Two-tailed $p$-values below 0.05 were considered statistically significant. $\left({ }^{*}\right) p<0.05,\left({ }^{* *}\right) p<0.01,\left({ }^{* * *}\right) p<0.001$ (b) Table summarizing the analyzed genes and the function of encoded proteins, as well as their involvement in main cellular processes. Up arrow (up-expression); Down arrow (down-expression).

We discovered that the diet rich in $\beta$-carbolines caused a significant decrease in caspase- 3 (CASP3) expression level of about $20 \%$, while the expression of the other analyzed genes involved in apoptosis remained on the level of the control animals. CASP3 is an effector factor responsible for the proteolytic cascade leading to cell death [39]. A similar effect in a decrease of caspase-3 activity was observed for 
the primary mesencephalic dopaminergic cell culture derived from embryonic mice after treatment with 9-methyl- $\beta$-carboline (a methylated derivative of norharmane) [26]. It can be assumed that the obtained result is a protective effect of $\beta$-carbolines. Moreover, studies on 9-me-BC revealed that $\beta$-carboline downregulated the expression of other proteins in apoptosis-relevant pathways like FAS, Gadd45a, and Hspb1, as well as reduced the expression of inflammation-related genes like Cxc19, Irf1, Fasl, Icam1, Tnf, and Vcam1 which are also relevant for apoptosis [26]. In the second group of genes, we noted an increase in the expression of SIRT2 $(\sim 17 \%)$ and SIRT6 $(\sim 12 \%)$, while the expression of SIRT1 and SIRT3 remained at the level of the control (Figure 5). It is known that sirtuins are involved in delaying the aging process [40]. SIRT2 upregulates the expression of FOXO3 target genes, thus decreasing ROS level [44], whereas SIRT6 plays essential roles in metabolic homeostasis, stress responses, genomic stability, and DNA repair [45]. Furthermore, SIRT6, a key modulator of the NFKB pathway, is involved in slowing the aging process [45]. According to Kanfi et al. [46], overexpression of SIRT6 in male mice significantly extends their life.

A significant increase in PGC-1 $\alpha(\sim 30 \%)$ and PINK1 ( 17\%) expression levels was also observed in the brains of treated rats. It is widely accepted that elevations in the level of PGC- $1 \alpha-$ a critical regulator of mitochondrial energy metabolism and biogenesis that is downregulated in PD brains-leads to protection against $\alpha$-synuclein-induced neurodegeneration in cell models [42]. PGC-1 $\alpha$ induces the expression of many ROS-detoxifying enzymes that protect neural cells from oxidative-stressor-mediated cell death [41], whereas PINK1 is a neuroprotector involved in preventing mitochondrial damage and promotes cell survival [30]. Moreover, PINK deficiency is associated with mitochondrial dysfunction, as well as with increased oxidative cellular stress and subsequent neuronal cell death [30].

We also observed significant differences in the expression of the third group of genes-those associated with neurogenerative changes. Decreases in LRRK2, SNCA, and PRKN (PARK2) of about $30 \%, 32 \%$, and $18 \%$ were observed, while PARK7 (DJ1), NDUFV2, and TAU expression increased by $30 \%, 20 \%$, and $5 \%$, respectively (Figure 5). It is known that the dysfunction of proteins encoding these genes is associated with the development and progression of neurodegenerative diseases, including Parkinson's disease [47]. The LRRK2, SNCA, and PRKN genes are the key factors influencing PD. It has been reported that dysfunction of LRRK2 may affect the accumulation of $\alpha$-synuclein and its pathology, altering cellular functions and signaling pathways though the kinase activation of LRRK2 [48]. On the other hand, the loss of parkin (PRKN) activity is the second most commonly known cause of PD [49]. However, in our research on experimental rats without a diagnosis of neurodegenerative disease, the expression level of the selected genes is related to the natural aging process and diet. The results should, therefore, be interpreted bearing in mind the physiological significance of the encoded proteins. Wild-type parkin plays an important role in mitochondrial quality control and turnover and promotes autophagy and the selective elimination of impaired mitochondria [49]. The precise physiological function of LRRK2 remains largely unknown, though recent studies have indicated that it is involved in cellular functions such as cytoskeletal maintenance, vesicle trafficking, autophagic protein degradation, and the immune system [48]. Some data have shown that not only the expression of the mutated form $\alpha$-synuclein, but also an excess of wild-type, can cause Parkinson's disease [42]. This contributes to abnormal protein aggregation, mitochondrial abnormalities, increased levels of ROS, and enhanced susceptibility to apoptosis [47]. Thus, the observed decrease in SNCA expression level may be seen as a beneficial result of enriching the diet with $\beta$-carboline-rich chicory extract. The upregulation of the PARK7 expression may also be seen as a positive result. It has been shown that wild-type PARK7 is implicated in antioxidant activity, modulation of transcription, and chaperone-like functions [50]. Moreover, PARK7 increases VMAT2 expression and function, protecting cells against dopamine toxicity and oxidative stress [51]. The other examined NDUFV2 gene, which was also overexpressed, is involved in controlling the stabilization of the assembly and optimal electron transport inside complex I, and also might act as an antioxidant electron carrier. Defects in NDUFV2 are associated with neurodegenerative disorders, including PD, but there is no literature data on NDUFV2 impairment during normal brain aging [52]. The minimal change in the expression level was observed for the gene 
encoding the TAU protein, which is involved in microtubule stabilization, membrane binding, and regulation of axon transport [43].

The data from gene expression studies correlate with the results of behavioral experiments, which show that treated rats were in significantly better condition than the control animals. These results may be considered an effect of the positive impact of a diet enriched with $\beta$-carbolines on aged individuals. Some literature data reported that 9-me-BC lowered the content of $\alpha$-synuclein in the primary dopaminergic cell cultures [27], as well as stimulated the gene expression of several important neurotrophic factors like Artn, Bdnf, Egln1, Tgfb2, and Ncam1, which are known to stimulate neurite outgrowth and exhibit neuroprotective and neuroregenerative properties to dopaminergic neurons [53].

Taken together, the presented results and literature data on neuroprotective and neuroactive effects suggest that further research is required to better understand the importance of $\beta$-carbolines in the aging process and neurodegeneration.

\section{Conclusions}

The addition of individual chemical standards of the $\beta$-carbolines harman and norharman to the diet of rats did not produce a very marked effect on the animals' behavior; however, they were transmitted to the blood in proportion to the amount eaten. The animal diet enriched with coffee substitute (chicory), a natural source of carbolines, resulted in a higher concentration of harman and norharman in the blood and had a positive effect on the animals' activity. The benefits of using a diet rich in $\beta$-carbolines were clearly visible in the results of behavioral studies on the rats, the increase in the level of harman and norharman in the blood plasma, and the results of the in vitro studies-particularly in terms of the gene expression levels in brain tissue of treated rats. We observed upregulation of genes associated with delaying aging processes and protecting oxidative stress but did not notice changes in expression of genes associated with processes leading to apoptosis. Furthermore, we reported a decrease of expression in the level of PD risk genes (PARK2, SNCA). The results obtained in the in vitro study on cell lines showed a protective effect of harman and norharman on aged human cells. These encouraging results provide the basis for further research into this subject.

Supplementary Materials: Supplementary materials can be found at http:/www.mdpi.com/1422-0067/21/15/ 5245/s1. Figure S1. MTT assay of harman and norharman cytotoxicity on HaCaT cells at various concentrations; Figure S2. Analysis of PD human cells viability after harmane and norharmane treatment. (a) Real-time analysis of AG20445 cells proliferation by the xCELLigence system for 6 days in the presence of 1,5,10, 25, 50, and $100 \mu \mathrm{M}$ harmane $(\mathrm{H})$, norharmane $(\mathrm{NH})$ or a mix of both $(\mathrm{H} / \mathrm{NH})$. Proliferation was monitored in 30 min intervals. Vertical lines on the graphs indicate the time points for adding compounds. (b) Flow cytometry analysis of apoptosis in AG20445 cells treated with 5, 10, and $25 \mu \mathrm{M}$ after $24 \mathrm{~h}$ with Casp 3/7-FITC/7-AAD dual staining. (c) Flow cytometry analysis of cell cycle in AG20445 after $24 \mathrm{~h}$ of $\mathrm{H}, \mathrm{NH}$, and $\mathrm{H} / \mathrm{NH}$ treatment $(5,10$, and $25 \mu \mathrm{M})$ The data are presented as the mean \pm SEM from three independent experiments. Statistical significance (ANOVA): $\left({ }^{*}\right) p<0.05,\left({ }^{* *}\right) p<0.01,\left({ }^{* * *}\right) p<0.001$; Figure S3. Mitochondrial oxidative stress analysis after harmane and norharmane treatment. (a) Confocal microscopy analysis of the mitochondrial membrane status in AG20445 after $24 \mathrm{~h}$ of harmane $(\mathrm{H})$, norharmane $(\mathrm{NH})$, or a mix of both $(\mathrm{H} / \mathrm{NH})$ treatment $(5,10$, and $25 \mu \mathrm{M})$ determined by JC- 1 staining. Left panels show JC-1 monomers (green fluorescence, Ex/Em 485/530 nm) which indicate a decrease of mitochondrial potential and middle panels present the J-aggregates (red fluorescence, Ex/Em 535/590 nm) which indicate high membrane potential. Merged images are on the right panels. (b) Flow cytometry analysis of changes in the mitochondrial membrane potential $(\Psi \mathrm{m})$. The fluorescence intensity histograms are representative of three independent experiments, whereas the bar graphs represent the mean fluorescence intensity \pm SEM. Statistical significance (ANOVA): $\left.\left(^{*}\right) p<0.05,{ }^{* *}\right) p<0.01,\left({ }^{* * *}\right) p<0.001$. CCCP $(50 \mu \mathrm{M})$ was used as a positive control to decrease $\Psi \mathrm{m}$; Table S1. List of primers and UPL probes used for real-time PCR analysis; Table S2. Mean content of fecal factors in 100g: insoluble dietary fiber (IDF), soluble dietary fiber (SDF), protein, fat, ash and water. Stage I and stage II.

Author Contributions: R.Z.-W., conception, design of the study, writing the original draft and final approval; A.F.-W., designed cell culture experiments, performed xCELLigence and confocal microscopy analyses, designed and conducted gene expression analysis in brain tissue by GPCR, analyzed and interpreted the data, and drafted the manuscript; P.P., animal experiment conductor, behavioral tests, and fecal analysis; S.M.-S., animal data interpretation and critical review; J.B., animal experiment supervision; E.W. (Elżbieta Wojtowicz), analysis and interpretation of $\beta$-carbolines data; K.P., $\beta$-carbolines method validation for different materials; D.G., designed and performed flow cytometry analyses, interpreted and described the cytometric results; W.K., involved in performing in vitro experiments; E.W. (Eliza Wyszko), responsible for the invention and supervising of the cell 
culture study of the project and analysis of gene expression level in rat brains, analyzed and interpreted the data, and drafted the manuscript. All authors have read and agreed to the published version of the manuscript.

Funding: This study was financially supported by the National Science Centre, Poland (Grant No. 2015/19/B/NZ9/01038).

Acknowledgments: The technical support provided by Faculty of Food Science and Nutrition, Poznań University of Life Sciences is gratefully acknowledged.

Conflicts of Interest: The authors declare no conflicts of interest.

\section{References}

1. Pfau, W.; Skog, K. Exposure to b-carbolines norharman and harman. J. Chromatogr. B 2004, 802, 115-126. [CrossRef] [PubMed]

2. Herraiz, T. Relative exposure to $\beta$-carbolines norharman and harman from foods and tobacco smoke. Food Addit. Contam. 2004, 21, 1041-1050. [CrossRef] [PubMed]

3. Celikyurt, I.K.; Utkan, T.; Gocmez, S.S.; Hudson, A.; Aricioglu, F. Effect of harmane, an endogenous $\beta$-carboline, on learning and memory in rats. Pharmacol. Biochem. Behav. 2013, 103, 666-671. [CrossRef] [PubMed]

4. Louis, E.D.; Michalec, M.; Jiang, W.; Factor-Litvak, P.; Zheng, W. Elevated blood harmane (1-methyl-9H-pyrido(3,4-b)indole) concentrations in Parkinson's disease. Neurotoxicology 2014, 40, 52-56. [CrossRef]

5. Youdim, M.B.H.; Edmondson, D.; Tipton, K.F. The therapeutic potential of monoamine oxidase inhibitors. Nat. Rev. Neurosci. 2006, 7, 295-309. [CrossRef]

6. Youdim, M.B.H.; Bakhle, Y.S. Monoamine oxidase: Isoforms and inhibitors in Parkinson's disease and depressive illness: Monoamine oxidase. Br. J. Pharmacol. 2009, 147, S287-S296. [CrossRef]

7. Baum, S.S.; Hill, R.; Rommelspacher, H. Harman-induced changes of extracellular concentrations of neurotransmitters in the nucleus accumbens of rats. Eur. J. Pharmacol. 1996, 314, 75-82. [CrossRef]

8. Farzin, D.; Mansouri, N. Antidepressant-like effect of harmane and other $\beta$-carbolines in the mouse forced swim test. Eur. Neuropsychopharmcol. 2016, 16, 324-328. [CrossRef]

9. Li, S.; Teng, L.; Liu, W.; Cheng, X.; Jiang, B.; Wang, Z.; Wang, C. Pharmacokinetic study of harmane and its 10 metabolites in rat after intravenous and oral administration by UPLC-ESI-MS/MS. Pharm. Biol. 2016, 54, 1768-1781. [CrossRef]

10. Paul, H.A.; Bomhof, M.R.; Vogel, H.J.; Reimer, R.A. Diet-induced changes in maternal gut microbiota and metabolomic profiles influence programming of offspring obesity risk in rats. Sci. Rep. 2016, 6, 20683. [CrossRef]

11. Gonzalez-Fuentes, J.; Moya, C.; Castro-Vázquez, L.; Lozano, M.; Marcos, P.; Plaza-Oliver, M.; Rodríguez-Robledo, V.; Santander-Ortega, M.; Villaseca-González, N.; Arroyo-Jimenez, M. Neuroprotective natural molecules, from food to brain. Front. Neurosci. 2018, 12, 1-8. [CrossRef] [PubMed]

12. Martinez-Morales, P.L.; Liste, I. Stem cells as in Vitro model of Parkinson's disease. Stem Cells Int. 2012, 2012, 980941.

13. Piechowska, P.; Zawirska-Wojtasiak, R.; Mildner-Szkudlarz, S. Bioactive $\beta$-carbolines in food: A review. Nutrients 2019, 11, 814. [CrossRef] [PubMed]

14. Sarkar, S.; Shmatova, J.; Nenajdenko, V.; Bhadra, K. Trifluoromethylaterd carboline compounds targetin DNA: Synthesis, binding and anti-proliferative effects on human cancer cell lines. Bioorg. Chem. 2019, 80, 61-79. [CrossRef]

15. Sengupta, P. The laboratory rat: Relating its age with human's. Int. J. Prev. Med. 2013, 4, 624-630.

16. Wojtowicz, E.; Zawirska-Wojtasiak, R.; Przygoński, K.; Mildner-Szkudlarz, S. Bioactive $\beta$-carbolines norharman and harman in traditional and novel raw materials for chicory coffee. Food Chem. 2015, 175, 280-283. [CrossRef]

17. Adachi, J.; Mizoi, Y.; Naito, T.; Yamamoto, K.; Fujiwara, S.; Ninomiya, I. Determination of $\beta$-carbolines in foodstuffs by high-performance liquid chromatography and high-performance liquid chromatography-mass spectrometry. J. Chromatogr. A 1991, 538, 331-339. [CrossRef] 
18. Zheng, W.; Wang, S.; Barnes, L.F.; Guan, Y.; Louis, E.D. Determination of harmane and harmine in human blood using reversed-phased high-performance liquid chromatography and fluorescence detection. Anal. Biochem. 2000, 279, 125-129. [CrossRef] [PubMed]

19. Porsolt, R.D.; Le Pichon, L.; Jalfre, M. Depression: A new animal model sensitive to antidepressant treatments. Nature 1977, 266, 730-732. [CrossRef]

20. Asp, N.G.; Johansson, C.G.; Hallmer, H.; Siljeström, M. Rapid enzymatic assay of insoluble and soluble dietary fiber. J. Agric. Food Chem. 1983, 31, 476-482. [CrossRef]

21. Zawirska-Wojtasiak, R.; Piechowska, P.; Wojtowicz, E.; Przygoński, K.; Mildner-Szkudlarz, S. Bioactivity of selected materials for coffee substitute. PLoS ONE 2018, 13, e0206762. [CrossRef] [PubMed]

22. Ke, N.; Wang, X.; Xu, X.; Abassi, Y.A. The xCELLigence system for real-time and label-free monitoring of cell viability. Methods Mol. Biol. 2011, 740, 33-43. [PubMed]

23. Li, S.; Zhang, Y.; Deng, G.; Wang, Y.; Qi, S.; Cheng, X.; Ma, Y.; Xie, Y.; Wang, C. Exposure Characteristics of the Analogous $\beta$-Carboline Alkaloids Harmaline and Harmine Based on the Efflux Transporter of Multidrug Resistance Protein 2. Front. Pharmacol. 2017, 8, 541. [CrossRef]

24. Dai, J.; Dan, W.; Schneider, U.; Wang, J. $\beta$-Carboline alkaloid monomers and dimers: Occurrence, structural diversity, and biological activities. Eur. J. Med. Chem. 2018, 157, 622-656. [CrossRef] [PubMed]

25. Ishida, J.; Wang, H.-K.; Bastow, K.F.; Hu, C.-Q.; Lee, K.-H. Antitumor agents 201.1 Cytotoxicity of harmine and $\beta$-carboline analogs. Bioorg. Med. Chem. Lett. 1999, 9, 3319-3324. [CrossRef]

26. Hamann, J.; Wernicke, C.; Lehmann, J.; Reichmann, H.; Rommelspacher, H.; Gille, G. 9-Methyl- $\beta$-carboline up-regulates the appearance of differentiated dopaminergic neurones in primary mesencephalic culture. Neurochem. Int. 2008, 52, 688-700. [CrossRef] [PubMed]

27. Polanski, W.; Enzensperger, C.; Reichmann, H.; Gille, G. The exceptional properties of 9-methyl- $\beta$-carboline: Stimulation, protection and regeneration of dopaminergic neurons coupled with anti-inflammatory effects. J. Neurochem. 2010, 113, 1659-1675. [CrossRef]

28. Hamann, J.; Rommelspacher, H.; Storch, A.; Reichmann, H.; Gille, G. Neurotoxic mechanisms of 2,9-dimethyl-beta-carbolinium ion in primary dopaminergic culture. J. Neurochem. 2006, 98, 1185-1199. [CrossRef]

29. Poon, R.Y. Cell cycle control: A system of interlinking oscillators. Methods Mol. Biol. 2016, 1342, 3-19.

30. Kitagishi, Y.; Nakano, N.; Ogino, M.; Ichimura, M.; Minami, A.; Matsuda, S. PINK1 signaling in mitochondrial homeostasis and in aging (Review). Int. J. Mol. Med. 2016, 39, 3-8. [CrossRef]

31. Pan, Y.; Nishida, Y.; Wang, M.; Verdin, E. Metabolic regulation, mitochondria and the life-prolonging effect of rapamycin: A mini-review. Gerontology 2012, 58, 524-530. [CrossRef] [PubMed]

32. Zorova, L.D.; Popkov, V.A.; Plotnikov, E.Y.; Silachev, D.N.; Pevzner, I.B.; Jankauskas, S.S.; Babenko, V.A.; Zorov, S.D.; Balakireva, A.V.; Juhaszova, M.; et al. Mitochondrial membrane potential. Anal. Biochem. 2018, 552, 50-59. [CrossRef] [PubMed]

33. Lehmann, J. Antioxidant properties of $\beta$-carbolines. In Isoquinolines and Beta-Carbolines as Neurotoxins and Neuroprotectants: New Vistas in Parkinson's Disease Therapy. Current Topics in Neurotoxicity, 1st ed.; Springer: Boston, MA, USA, 2012; pp. 133-144.

34. Moura, D.J.; Richter, M.F.; Boeira, J.M.; Pêgas Henriques, J.A.; Saffi, J. Antioxidant properties of $\beta$-carboline alkaloids are related to their antimutagenic and antigenotoxic activities. Mutagenesis 2007, 22, $293-302$. [CrossRef] [PubMed]

35. Li, S.P.; Wang, Y.W.; Qi, S.L.; Zhang, Y.P.; Deng, G.; Ding, W.Z.; Ma, C.; Lin, Q.Y.; Guan, H.D.; Liu, W.; et al. Analogous $\beta$-Carboline Alkaloids Harmaline and Harmine Ameliorate Scopolamine-Induced Cognition Dysfunction by Attenuating Acetylcholinesterase Activity, Oxidative Stress, and Inflammation in Mice. Front. Pharmacol. 2018, 9, 346. [CrossRef] [PubMed]

36. Kuhn, W.; Müller, T.; Große, H.; Dierks, T.; Rommelspacher, H. Plasma levels of the beta-carbolines harman and norharman in Parkinson's disease. Acta Neurol. Scand. 1995, 92, 451-454. [CrossRef]

37. Rommelspacher, H.; Schmidt, L.G.; May, T. Plasma norharman (beta-carboline) levels are elevated in chronic alcoholics. Alcohol. Clin. Exp. Res. 1991, 15, 553-559. [CrossRef]

38. Gruss, M.; Appenroth, D.; Flubacher, A.; Enzensperger, C.; Bock, J.; Fleck, C.; Gille, G.; Braun, K. 9-Methyl- $\beta$-carboline-induced cognitive enhancement is associated with elevated hippocampal dopamine levels and dendritic and synaptic proliferation. J. Neurochem. 2012, 121, 924-931. [CrossRef] 
39. Kiraz, Y.; Adan, A.; Kartal Yandim, M.; Baran, Y. Major apoptotic mechanisms and genes involved in apoptosis. Tumor Biol. 2016, 37, 8471-8486. [CrossRef]

40. Giblin, W.; Skinner, M.E.; Lombard, D.B. Sirtuins: Guardians of mammalian healthspan. Trends Genet. 2014, 30, 271-286. [CrossRef]

41. Anderson, R.; Prolla, T. PGC-1 $\alpha$ in aging and anti-aging interventions. BBA Gen. Subj. 2009, 1790, $1059-1066$. [CrossRef]

42. Stefanis, L. $\alpha$-Synuclein in Parkinson's disease. CSH Perspect. Med. 2012, 4, a009399.

43. Zhang, X.; Gao, F.; Wang, D.; Li, C.; Fu, Y.; He, W.; Zhang, J. Tau pathology in Parkinson's disease. Front. Neurol. 2018, 9, 809. [CrossRef] [PubMed]

44. Wang, F.; Nguyen, M.; Qin, F.X.; Tong, Q. SIRT2 deacetylates FOXO3a in response to oxidative stress and caloric restriction. Aging Cell 2007, 6, 505-514. [CrossRef] [PubMed]

45. Jia, G.; Su, L.; Singhal, S.; Liu, X. Emerging roles of SIRT6 on telomere maintenance, DNA repair, metabolism and mammalian aging. Mol. Cell. Biochem. 2012, 364, 345-350. [CrossRef]

46. Kanfi, Y.; Naiman, S.; Amir, G.; Peshti, V.; Zinman, G.; Nahum, L.; Bar-Joseph, Z.; Cohen, H.Y. The sirtuin SIRT6 regulates lifespan in male mice. Nature 2012, 483, 218-221. [CrossRef]

47. Galindo, M.F.; Solesio, M.E.; Jordan, J. Role of mitochondrial fission and mitophagy in Parkinson's disease. In Autophagy: Cancer, Other Pathologies, Inflammation, Immunity, Infection, and Aging, 1st ed.; Academic Press: Main St. Salt Lake City, UT, USA; Volume 4, pp. 213-225.

48. Rui, Q.; Ni, H.; Li, D.; Gao, R.; Chen, G. The role of LRRK2 in neurodegeneration of Parkinson disease. Curr. Neuropharmacol. 2018, 16, 1348-1357. [CrossRef]

49. Dawson, T.M.; Dawson, V.L. The role of parkin in familial and sporadic Parkinson's disease. Mov. Disord. 2010, 25, 32-39. [CrossRef]

50. Kahle, P.J.; Waak, J.; Gasser, T. DJ-1 and prevention of oxidative stress in Parkinson's disease and other age-related disorders. Free Radical Biol. Med. 2009, 47, 1354-1361. [CrossRef]

51. Lev, N.; Barhum, Y.; Pilosof, N.S.; Ickowicz, D.; Cohen, H.Y.; Melamed, E.; Offen, D. DJ-1 protects against dopamine toxicity: Implications for Parkinson's disease and aging. J. Gerontol. A Biol. 2013, 68, $215-225$. [CrossRef]

52. Tatarkova, Z.; Kovalska, M.; Timkova, V.; Racay, P.; Lehotsky, J.; Kaplan, P. The effect of aging on mitochondrial complex I and the extent of oxidative stress in the rat brain cortex. Neurochem. Res. 2016, 41, 2160-2172. [CrossRef]

53. Keller, S.; Polanski, W.H.; Enzensperger, C.; Reichmann, H.; Hermann, A.; Gille, G. 9-Methyl- $\beta$-carboline inhibits monoamine oxidase activity and stimulates the expression of neurotrophic factors by astrocytes. J. Neural. Transm. 2020, 127, 999-1012. [CrossRef] [PubMed] 